\title{
TWELVE BOTTLES OF WHISKEY
}

\author{
JACK WATSON*
}

This article provides an in-depth analysis of the history of certiorari and judicial review as it pertains to the rule of law. The article opens with a brief examination of the conviction of Nat Bell Liquors Ltd. during prohibition-era Edmonton in 1920, and explains how twelve bottles of whiskey brought about a sea change in the foundational law of Canada. The article details the development of judicial review, beginning in thirteenth century United Kingdom, noting its progression and change over the course of centuries. The article provides an account of certiorari as a replacement avenue where appeal is not available, and highlights notable Canadian jurisprudence from the early twentieth century to the present day.
Cet article brosse un tableau exhaustif de l'histoire des processus de révision judiciaire et de révision par voie de certiorari en ce qui a trait à la primauté du droit. Suivant un bref survol de la condamnation de Bell Liquors Ltd., à Edmonton, à l'époque de la Prohibition dans les années 1920, l'auteur explique comment 12 bouteilles de whisky ont entraîné une mer de changements aux lois fondamentales du Canada. L'article décrit l'évolution du processus de révision judiciaire au Royaume-Uni à partir du XIII siècle et il met en lumière les changements survenus au cours des siècles. Enfin, il présente le certiorari comme une autre avenue lorsque le recours en appel n'est pas une option et il illustre des cas notables dans la jurisprudence canadienne depuis le début du $X X^{e}$ siècle jusqu'à aujourd'hui.

\section{TABLE OF CONTENTS}

I. INTRODUCTION . . . . . . . . . . . . . . . . . . . . . . . . . . 10

II. The CASE For the Prosecution $\ldots \ldots \ldots \ldots \ldots \ldots \ldots \ldots \ldots \ldots \ldots$

III. The GRIEVANCE Of NAT BELL $\ldots \ldots \ldots \ldots \ldots \ldots \ldots \ldots \ldots \ldots \ldots \ldots$

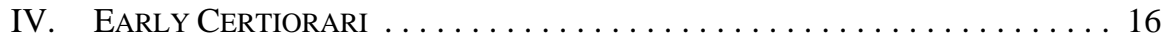

V. UnITED KINGDOM JUdGES SPEAK $\ldots \ldots \ldots \ldots \ldots \ldots \ldots \ldots \ldots \ldots \ldots$

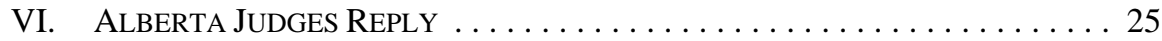

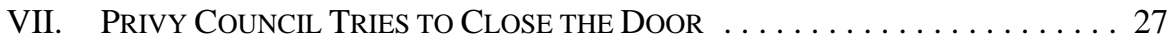

VIII. THE HORNS OF JURISDICTION BY THE MID-TwENTIETH CENTURY . . . . . . 33

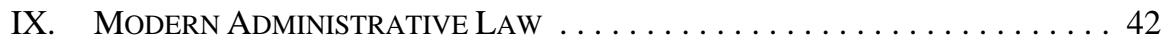

X. Constitutionalism Prevails . . . . . . . . . . . . . . . . . . . . 47

The emphatical words of magna carta, spoken in the person of the king, who in judgment of law (says Sir Edward Coke) is ever present and repeating them in all his courts, are these; "nulli vendemus, nulli negabimus, aut differemus rectum vel justitiam [to none will we sell, to none deny, to none delay, either right or justice]”... [N]o commands or letters shall be sent under the great seal, or the little seal, the signet, or privy seal, in disturbance of the law; or to disturb or delay common right: and, though such commandments should come, the judges shall not cease to do right. ${ }^{1}$

* Jack Watson is a “millennial” judge, appointed in 2000 to the Court of Queen’s Bench and elevated to the Court of Appeal in 2006. He was also a bemused "witness to history” during 27 years as a Crown Counsel in all levels of Alberta Courts, notably in the Court of Appeal and the Supreme Court of Canada on numberless occasions along with many years of involvement as a lecturer at the University of Alberta, Faculty of Law and scores of other courses and seminars and with various roles for the Canadian Bar Association and Law Society of Alberta.

$1 \quad$ William Blackstone, Commentaries on the Laws of England, vol 1 (Oxford: Clarendon Press, 1765) at 137-38. 


\section{INTRODUCTION}

The adolescent province of Alberta was a considerable and difficult distance from Westminster. But it had already figured in the promulgation of a central point of the rule of law even before a shady character named Bolsing inveigled a warehouseman named Angel to sell him twelve bottles of whiskey on a brisk October day in 1920 Edmonton. ${ }^{2}$ This dealing set in motion a chain of events concerning the writ of certiorari which, nearly a century later, has evolved into a constitutionalized concept of judicial review, making the rule of law a practical reality in Canada.

A year before Bolsing's purchase, the Privy Council had ruled in a case called Board ${ }^{3}$ that the Matrimonial Causes Act, $1857^{4}$ was in force in Alberta. To many people either in London or Alberta, except presumably Mary and William Board, the existence of this statute would probably have seemed neither here nor there. But the fact that it was here meant a lot here and there, whether William and Mary knew it or not. The 1907 statute $^{5}$ which created the Supreme Court of Alberta had blessed that Court with this inherited divorce jurisdiction. ${ }^{6}$ The Privy Council proclaimed "[i]f the right exists, the presumption is that there is a Court which can enforce it, for if no other mode of enforcing it is prescribed, that alone is sufficient to give jurisdiction to the King's Courts of justice."7

Nicely said, but so what? It was one thing for the Privy Council to say the Supreme Court of Alberta - as the manifestation of the King's Court of Justice and Equity in Alberta had jurisdiction to decide if a right existed in law. It was another to say the Courts had the power to take steps to enforce the right (ubi jus ibi remedium). It was yet a third thing to have a proceeding or form of action to get the question into the Court lawfully in the first place. Board had a statute to call in aid, so the Diceyan view of Parliamentary sovereignty would not be dramatically affronted by that foray into judicial creativity. ${ }^{8}$

The events were at the heart of Edmonton in the Goodridge Block at the corner of Namayo Avenue (now 97 Street) and Jasper Avenue. That impressive brick building was constructed between 1911 and1912 with Edwardian style and brick and stone detailing (City of Edmonton Historic Resource Management Program, “Goodridge Building,” online: <http://www.edmonton.ca/city_government/documents/infra Plan/GoodridgeBlock.pdf>). It was occupied from 1930 to 1989 by a hardware business known from 1942 to 1989 as WW Arcade. It currently houses a high-end restaurant. The case moved rapidly from police seizures on 2 October 1920 to conclusion of trial on 20 October 1920 (prominently reported in the Edmonton Bulletin of the period). See "Police Seize 3 Carloads of Liquor in City," The Morning Bulletin (4 October 1920) 1; "Nat Bell Case Closed; Awaits the Argument," The Morning Bulletin (20 October 1920) 3.

Board v Board, [1919] AC 956 (PC) [Board].

(UK), 20 \& 21 Vict, c 85.

Supreme Court Act, SA 1907, c 3.

Board, supra note 3 at 960 .

Ibid at 962.

Dicey's attempt to gather together the great themes and concepts of the ambiguous expanse of the unwritten English Constitution had a first edition in 1885 (AV Dicey, Lectures: Introductory to the Study of the Law of the Constitution (London, UK: Macmillan, 1885). The sixth edition by 1920 was in wide circulation (AV Dicey, Introduction to the Study of the Law of the Constitution, 6th ed (London, UK: Macmillan, 1902 [Dicey, 6th ed]). 
However, the prosecution of Nat Bell Liquors was different from Board. In Nat Bell Liquors, ${ }^{9}$ an Edmonton magistrate had jurisdiction to execute the prohibitionist fervour of the times. Antipathy to liquor was culturally omnipresent. It had been entrenched in the restrictive provisions of The Liquor Act of Alberta. ${ }^{10}$ There was no right of appeal from the conviction, fine, and forfeiture made by the magistrate against the company.

As Lord Sumner later said in Nat Bell Liquors, the exercise of jurisdiction of the Alberta Legislature to enact The Liquor Act was according to "the people's wishes."11 But constitutional suspicion fell on parts of that Act. Consequently, the conviction and forfeiture order in Nat Bell Liquors might have troubled the Privy Council more had the relevant parts of the Act not been worded in such a way as to remain within "matters of a local nature."

The salient sections of the The Liquor Act for this case had been worded at least to appear to respect the expected immunity of interprovincial and international trade from provincial interference. Moreover, the sections relevant to the prosecution of Nat Bell Liquors were severable from other elements of the statute of a "stringent character" which were quite likely ultra vires. ${ }^{12}$ As to the provisions that were used to prosecute Nat Bell Liquors, Lord Sumner trenchantly observed, "although this Act, like many other Liquor Acts, has been made increasingly restrictive of individual freedom and enforced by legal measures of progressive severity, its competence depends on its general character and objects and not on the weight with which the Legislature lays its hand on those who violate its statutes.”13

Importantly, Lord Sumner added that the power of the executive to order forfeiture of substantial property as an ancillary sanction to a conviction of such an offence fell within the "Imposition of Punishment by Fine, Penalty, or Imprisonment for enforcing any Law of the Province" ${ }^{14}$ even though the word "forfeiture" was not listed in section 92(15) of the Constitution Act, $1867 .{ }^{15}$ The Privy Council installed forfeiture within penalty so as not to "rob the Provincial Legislature of the power, for example, of depriving an illegal vendor of poisons of his stock in trade and ... leave it to him ready for further operations on his release from gaol."16

$R v$ Nat Bell Liquors, Ltd,[1922] 2 AC 128 (PC) [Nat Bell Liquors].

SA 1916, с 4.

Nat Bell Liquors, supra note 9 at 135. Lord Sumner was referring to the fact that The Liquor Act was a product of the process under The Direct Legislation Act, SA 1913, c 3, passed in March 1913 by the AL Sifton administration (Sifton being the former Chief Justice of Alberta). That Act provided for two basic ways in which the public could directly require or approve legislative enactments although they could not directly enact or nullify laws. One way had it that if a specified percentage of the electors petitioned for an Act to be passed, the Legislature would be expected to pass it and if it did not, the government had to submit it to a plebiscite, and if then approved, it had to be passed by the Legislature without amendment. In 1915, the voters solidly endorsed liquor prohibition, which resulted in the The Liquor Act (Nat Bell Liquors, ibid at 133-34). As The Direct Legislation Act was not challenged before the Privy Council, Lord Sumner did not have occasion to address its validity (ibid at 135).

Ibid at 137.

Ibid at 138.

Constitution Act, 1867 (UK), 30 \& 31 Vict, c 3, s 92(15), reprinted in RSC 1985, App II, No 5.

Nat Bell Liquors, supra note 9 at 138.

Ibid. 
The opposite view would indeed have very seriously restricted the enforcement capacity of the province. That is because the practical scope and reach of the legislative powers of any province could well depend on whether an ability to forfeit went along with other punitive sanctions the province might enact. In Nat Bell Liquors, the forfeiture order was significant.

The Privy Council's blessing of the forfeiture power by this rather non-technical, in other words, purposive interpretation helped avoid an early stifling of Canada's federalism. At the time, and despite the Constitution being a "living tree capable of growth and expansion within its natural limits," the Constitutional division of powers was such that the provinces and Dominion were rather stuck within those limits. ${ }^{17}$ As Lord Atkin explained, the division of powers was a matter of "watertight compartments.",18

It took decades for the first half of the expression "living tree" to come to dominate the "natural limits," at least analytically, ${ }^{19}$ and to support a new “dominant tide." ${ }^{20}$ Back then, this encouragement of the practical regulatory capacity of a province — a finding shoehorned into the ultimate decision of Nat Bell Liquors — was no small contribution to federalism. But as important a point as this was, our story concerns something else.

\section{The Case for the Prosecution}

Those with influence on Alberta's legislature chose to set the provincial face against liquor, at least insofar as rendering it a rigidly regulated activity. Alberta's Famous Five were not merely joined in the view that women deserved equal treatment, but in the view that poverty, crime, disease, and domestic abuse were linked to misuse of alcohol. ${ }^{21}$

Ironically, as noted by Justice Beck of the Appellate Division in Nat Bell Liquors, "[s]omething like 12 other liquor export houses were doing business in Edmonton."22 The

$17 \quad$ Edwards v Canada (AG), [1930] AC 124 at 136 (PC).

18 Canada (AG) v Ontario (AG), [1937] AC 326 at 354 (PC). Part of this "watertight compartment” approach, supported by the word "exclusive" in the Constitution Act, 1867, seems to have been intended to protect provincial legislative authority from federal invasion: see e.g. Citizens Insurance v Parsons, [1881] 7 AC 96 (PC).

19 Reference re Employment Insurance Act (Can), ss 22 and 23, 2005 SCC 56, [2005] 2 SCR 669 at para 9; Canadian Western Bank v Alberta, 2007 SCC 22, [2007] 2 SCR 3 at paras 21-24, 30-31, 69.

20 Reference Re Securities Act, 2011 SCC 66, [2011] 3 SCR 837 at paras 55-57, 62. Long before this reference, it was well accepted that as for deciding which level of government possessed the power, the "courts will be the authority in the community to control the limits of the respective sovereignties" (Northern Telecom v Communication Workers, [1983] 1 SCR 733 at 741).

21 Nellie McClung, Henrietta Muir Edwards, Emily Murphy, Louise Crummy McKinney, and Irene Parlby. See generally, Grant MacEwan, ... And Mighty Women Too: Stories of Notable Western Canadian Women (Saskatoon: Western Producer Prairie Books, 1975).

$22 \quad R v$ Nat Bell Liquors Ltd (No 2) (1921), 16 Alta LR 149 at 181 (SC (AD)) [Nat Bell Liquors (AD)]. The Court later ruled that there was no ability to appeal by leave or right to the Supreme Court of Canada ( $R v$ Nat Bell Liquors Limited, [1921] 1 WWR 1068 (Alta SC (AD)). There had been legislation to bar criminal appeals to the Supreme Court, and the question whether this was criminal despite being provincial law was a distraction here too. 
Edmonton population in 1920 was approximately 61,045 souls (an explosion in size from 8,350 in 1904). ${ }^{23}$

Locally, things were fine for chemists, druggists, and clergymen in respect of liquor kept for dispensing and sacramental purposes, ${ }^{24}$ but Nat Bell Liquors Ltd. - although incorporated by Dominion Charter in 1917 and doing a large (\$15,000 per month), lawful, and provincially licensed business in Edmonton ${ }^{25}$ — had to mind its Ps and Qs. It was in the export business and could hardly be said to be selling liquor for "mechanical or scientific purposes" under The Liquor Act. ${ }^{26}$ Indeed, police had charged the company previously for making a false return, even though the admitted defect was merely a mistake about two cases of goods. ${ }^{27}$

Neither Nathan Bell nor his partner William Sugarman was within earshot when Bolsing, who was posing as a working carpenter and who was armed with marked money provided by the police, talked to Gordon Angel at the company warehouse. Bolsing said he acquired twelve bottles of whiskey for $\$ 45$ at the premises on that fateful day (shortly followed by a large police swoop). ${ }^{28}$ Little of Bolsing's testimony had anything to do with Bell or Sugarman. Bell asserted under oath that he never allowed any sales in Alberta.

Bell's assertion of non-involvement was supported by evidence of Miss Dudley, a "girl typist." 29 Snidely, the prosecution argued "what other position she was likely to take.” The alleged proof of any involvement on the part of Bell or his partner Sugarman is revealed for all its deficiency in the judgments of the certiorari level ${ }^{30}$ and of the Appellate Division. Certainly several Alberta judges found it inconceivable that guilt, in the first place, and justification for forfeiture, in the second, could be said to have been made out beyond a reasonable doubt.

Moreover, star witness and agent provocateur Bolsing had a prior conviction for theft, "and when cross-examined about it unsuccessfully denied the conviction" as noted by Lord Sumner. ${ }^{31}$ Bolsing had, moreover, been rather pressing and persistent to get the deal done (no doubt at the instigation of the police), having taken three days of visits upon Angel to conclude the transaction. ${ }^{32}$ As Lord Sumner mildly put it, this was a “test” of the company's good conduct. ${ }^{33}$

Population History, online: City of Edmonton <http://www.edmonton.ca/city_government/facts_ figures/population-history.aspx>.

Nat Bell Liquors, supra note 9 at 139.

Ibid at 132; Nat Bell Liquors (AD), supra note 22 at 181.

Supra note 10, s 11.

Nat Bell Liquors (AD), supra note 22 at 182.

Nat Bell Liquors, supra note 9 at 133.

Ibid; Nat Bell Liquors (AD), supra note 22 at 182.

$R v$ Nat Bell Liquors, Ltd (1920), [1921] 1 WWR 136 (Alta Sup Ct) [Nat Bell Liquors (Sup Ct)].

Nat Bell Liquors, supra note 9 at 133.

Ibid.

Ibid at 132. 
Notwithstanding the evidentiary gaps, the magistrate found the company "did unlawfully keep for sale a quantity of liquor, contrary to the provisions of The Liquor Act," ${ }^{, 34}$ presumably invoking section 23 of the statute which provided that: "No person shall, within the Province of Alberta, by himself, his clerk, servant or agent, expose or keep for sale or directly or indirectly or upon any pretence or upon any device sell or barter, or offer to sell or barter ... to any other person any liquor except as authorized by this Act." ${ }^{35}$

One says "presumably" because the record is not clear whether any formal particularity of the accusation against Nat Bell Liquors was ever provided before trial. At any rate, the dearth of specificity seems matched by the dearth of hard evidence implicating the company. Significantly, Lord Sumner was unmoved by the suggestion there was not enough to the case. $^{36}$

Unimpeded by any doubts, the magistrate fined the company $\$ 200$ and followed up with an order under section 80 of The Liquor Act that forfeited the entire large stock of whiskey in the company warehouse in Edmonton. ${ }^{37}$ As noted above, the Privy Council could find no independent reason to disturb that on constitutional grounds. The forfeiture was said to have amounted to the colossal sum of $\$ 50,000$, or about one half of the company’s annual sales. ${ }^{38}$

\section{THE GRIEVANCE OF NAT BELL}

No doubt all this seemed rather unfair to Nat Bell. True, he may not have felt himself comparable to Voltaire, who two centuries earlier had been

sent to the Bastille for a poem which he had not written, of which he did not know the author, and with the sentiment of which he did not agree. What adds to the oddity, in English eyes, of the whole transaction is that the Regent treated the affair as a sort of joke, and, so to speak, "chaffed" the supposed author of the satire "I have seen" on being about to pay a visit to a prison which he "had not seen."39

Nat Bell Liquors (Sup Ct), supra note 30 at 137.

The Liquor Act, supra note 10, s 23.

Nat Bell Liquors (Sup Ct), supra note 30 at 143-45.

Supra note 10, s 80, as amended by SA 1917, c 22, s 15; Nat Bell Liquors (AD), supra note 22 at 153 54.

Ibid at 167 . To fully appreciate the implications of that vast sum of money, Alberta was in the grip of an economic crisis and wheat prices had plunged. In the same 20 October 1920 edition of The Morning Bulletin reporting on the trial of Nat Bell Liquors (supra note 2), six pounds of British Columbia onions were priced at 25 cents, cabbage at three cents a pound, five pounds of corn meal at 35 cents, and five cents would buy you a copy of the Bulletin. The City authorized an annual salary for an official of the telephone department of \$3,000 (ibid at 3). The Morning Bulletin of 4 October 1920, reported an original seizure of " 3 carloads" of liquor [worth an estimated $\$ 160,000$ ] by "the guardians of the law" (supra note 2). It added, "the present affair goes to the credit of Detective Sergeant Gilliam and the morality squad" working "to the detriment of the breakers of the law." The rest, not forfeited, was not whiskey, but was champagne, rum, and so forth.

Dicey, 6th ed, supra note 8 at 186, citing Gustave Desnoiresterres, Voltaire et la Société Au XVIII ${ }^{E}$ Siècle: La Jeunesse de Voltaire, 2d ed (Paris: Didier, 1871) at 344-64. Dicey adds that despite being a literary hero in his country, Voltaire was in 1725 "lured off from the table of a Duke, and was thrashed by lackeys in the presence of their noble master; he was unable to obtain either legal or honourable redress, and because he complained of this outrage, paid a second visit to the Bastille” (Dicey, 6th ed, ibid). 
Nevertheless, Nat Bell was arguably in an analogous position to Voltaire. Both men faced what was allegedly abusive use of the power of the state, albeit that Voltaire's position was chastened even more arbitrarily and more harshly.

As for the police work in Nat Bell Liquors, the random virtue testing and entrapment of the company that occurred was not a substantial topic of discussion under Canadian law, let alone an established basis for stopping a prosecution for another seven decades. ${ }^{40}$ Lord Sumner, the author of the famous case of $\mathrm{Ibrahim}^{41}{ }^{41}$ was not evidently asked to reflect on any such police mischief in his reasons. All the same, Nat Bell engaged counsel to do something about his company’s stores of drinking whiskey and his company’s good name.

This resulted in an application for certiorari. That motion ended up in the Supreme Court of Alberta before Justice J.D. Hyndman. To get to Justice Hyndman, the parties passed through the relatively new Edmonton courthouse. This was a grim and stolid but outwardly impressive looking sandstone structure, that, regrettably, the designers underestimated. Almost immediately the contents filled it, forcing a course of "musical offices." 42

There was, however, a (mildly art deco) grandeur of the place, notably the heavy and august central staircase surrounded by dark, solid wood doors and brass fixtures. Entry to the main hall would have immediately left the impression that these stairs led someplace important, as indeed they did. ${ }^{43}$

The building was already crowded and overtaxed when Justice Hyndman heard Nat Bell Liquors. ${ }^{44}$ Despite an annex built decades later, the courthouse remained in that condition for the rest of Hyndman's career and indeed, for the next half century. But in 1920 it had a stern solidity in the centre of a dusty prairie capital that asserted the rule of law. That rule promised some curtailment of the discretion of the executive, even back in $1920 .{ }^{45}$

The approach of Justice Hyndman to the company's conviction and the forfeiture order was in plain language, direct and forthright. So, certainly, were the views of the Appellate Division majority. Nevertheless, the Privy Council found their approach to certiorari to be too controversial to let stand. What was the reluctance of the Privy Council all about? To answer this question we must leave the story of Nat Bell Liquors temporarily for a superficial sweep through history. Part VI, below.

41

See $R v$ Mack, [1988] 2 SCR 903. But note the comments of Justice Stuart of the Appellate Division in Ibrahim $v$ The King, [1914] AC 599 (PC) [Ibrahim].

David Mittelstadt, Foundations of Justice: Alberta's Historic Courthouses (Calgary: University of Calgary Press, 2005) at 166.

For the judges, that place was crammed. Appointed in 1914, Hyndman was offered space by the Deputy Minister of Public Works, John Stocks by eliminating a closet and then cutting an existing office (occupied by another judge) into two (ibid).

Nat Bell Liquors (Sup Ct), supra note 30.

Lord Parmoor in AG v De Keyser's Royal Hotel, Ltd, [1920] UKHL 1, [1920] AC 508 at 568 observed: "The Royal Prerogative has of necessity been gradually curtailed, as a settled rule of law has taken the place of an uncertain and arbitrary administrative discretion.” 


\section{EARLY CERTIORARI}

Certiorari, as it had come to Justice Hyndman, was a form of judicial (but prerogative) writ that was said to have been adapted towards its modern form in 1642 from a much older formula. The idea on which it is based can be traced to the 1270 s, just before the arrival of Edward I. ${ }^{46}$ In basics, it was a tool almost in the nature of a royal directive whereby the royal courts could pull cases into their jurisdiction to review what happened there. The word itself is as old as Ulpian. ${ }^{47}$

Certiorari became linked to the writ of error of the thirteenth and fourteenth centuries as well as to the writs of false judgment called recordari facias (to county courts) and accedas ad curiam (to courts baron). The writs of false judgment involved instructions to put together a record so the King's Bench could take a look at what happened, although it has been said that their principal aim was to punish offending adjudicators. ${ }^{48}$

Removing cases to the King was not a new idea: "[s]ince the Assize of Northampton, 1176, justices in eyre had been required to report any case 'so great that it cannot be decided without the lord King, or the like' to the king, or [to] 'those who shall be in his place.," 49

Shortly after the Magna Carta was created in 1215, local bigwigs of the counties were taking assizes..$^{50}$ As they were not particularly learned in the law, "nor was the central government especially anxious to protect their dignity," writs to take the bigger matters to Westminster emerged. ${ }^{51}$ The word "certiorari” formed part of expressions such as "rex ... certiorari et errorem si quis intervenit corrigi volens" ("The king ... wishing to be informed and that error should be corrected if any has occurred”). ${ }^{52}$

The royal interest in inferior courts was for the executive, and not to empower the judiciary as a third branch of government (John Locke would not be born for centuries). In early times the royal courts raised revenue as well and were altruistic about installing consensus legal principles into local (and notably commercial) activity. But the ground for judicial power was being developed.

Edith G Henderson, Foundations of English Administrative Law: Certiorari and Mandamus in the Seventeenth Century (Cambridge, Mass: Harvard University Press, 1963) at 83.

47 Domitius Ulpianus (c. $170-228$ ) a Roman jurist of Tyrian ancestry. His use of the term is said to embrace both reporting and reviewing decisions. His prolific legal writing is credited as forming a third of the Institutes of Justinian. See generally Tony Honoré, Ulpian: Pioneer of Human Rights, 2d ed (Oxford: Oxford University Press, 2002). The records of Ulpian are not universally credited. For example, the exclusion of women from high office was said by the Privy Council in the famous case of Edwards v Canada (AG) (supra note 17) to have "found its way into the opinions of the Roman jurists, Ulpian (A.D. 211) laying it down. 'Feminae ab omnibus officiis civilibus vel publicis remotae sunt': Dig. 1.16.195."

48 Henderson, supra note 46 at 84.

$49 \quad$ Ibid at 84-85.

50 Ibid at 85 .

$51 \quad$ Ibid.

$52 \quad$ Ibid at 86, n 14. 
Even in the thirteenth century, suspicions arose in the executive about how the somewhat motley collection of writs of error, writs of false judgment, and certiorari might be used by those judges, howsoever asserted to be in the name of the King. Chapter 31 of the Statute of Westminster II was enacted in $1285,{ }^{53}$ apparently over judicial objection, to restrict judicial review to errors "on the face" of the record and to shift the rest of the subject matter to bills of exception. ${ }^{54}$

Despite some early efforts to get a more detailed record of what occurred to the royal court by certiorari (originally including a somewhat odd option of getting four knights to come and tell the story orally), the essence of the process seems to have been largely a matter of looking over the formal records, skimpy as they might be. ${ }^{55}$

Doing that more effectively was probably a factor driving a decision of a Chief Justice by the end of the sixteenth century to command that the record did not have to go to Westminster, but "ubicunque fuerimus in Anglia (wherever we may be in England)." 56 The subtle meaning of this directive - howsoever utilitarian a pronouncement by the Chief Justice this may have seemed to be at the time - implied that certiorari was a judicial power, and not one necessarily attached to the seat of executive government or of His Majesty. No small step itself.

Chapter 31 of the Statute of Westminster II was not any sort of nod to an incipient movement towards democracy. It was a rather plain effort to keep the courts out of the merits of lower decision making, notably that of the local justices, sheriffs, commissioners, and other local worthies carrying out the royal will.

The suggestion of getting bills to deal with the matter was not Parliamentary in spirit. It was not as if the King was particularly interested in endowing his legislators with enough enacting power to get in his way. After all, during the reign of Henry IV, albeit following an ordinance of his grandfather Edward III, a warrant for election to Parliament read "that no apprentice or other man of the law should be elected." ${ }^{\text {„57 }}$ Lord Chief Justice Edward Coke later observed that "never a good law made thereat" and subsequently this Parliament was referred to as "parliamentum indoctum" or "the lack-learning parliament."

Coke's own view of Parliaments was at best ambivalent and his interest in judicial authority more profound. Though he would not know it at the time, Coke's words energized the sponsors of the American revolution with what he said in Dr. Bonham's Case that "in many cases, the common law will controul acts of parliament, and sometimes adjudge them to be utterly void: for when an act of parliament is against common right and reason, or

\footnotetext{
$53 \quad$ Statute of Westminster, 1285 (UK), 13 Edw I, c 31.

Henderson, supra note 46 at 88-89.

Ibid at 89-90.

Ibid at 91-92.

John Lord Campbell, Lives of the Lord Chancellors and Keepers of the Great Seal of England, 4th ed (London: John Murray, 1856) vol 1 at 271. 
repugnant, or impossible to be performed, the common law will controul it, and adjudge such act to be void. $\$ 59$

If that broad notion caught on, perhaps judicial review by certiorari would have been an easier legal device to develop. But Lord Chancellor Ellesmere and the King were unmoved by the idea. Ellesmere wrote in his Observations on the Lord Coke's Reports:

\begin{abstract}
And for novelty in Doctor Bonham's case, the Chief Justice having no Precedent for him, but many Judgments against him, yet doth he strike in sunder the Bars of Government of the College of Physicians, and without any pausing on the Matter, frustrate the Patent of King [Henry VIII] whereby the college was erected, and tramples upon the Act of Parliament ... whereby that Patent was confirmed, blowing them both away as vain, and of no Value; and this is in Triumph of himself being accompanied but with the Opinion of one Judge only for the Matter in Law, when three other Judges were against him, which Case possesseth a better Room in the Press than is deserved. ${ }^{60}$
\end{abstract}

As judicial review was gathering steam by way of certiorari and its familiars, the executive between the thirteenth and seventeenth centuries tried to stem the writ. Nevertheless, the medieval version of "get me the file on this case" persisted. ${ }^{61}$ It expanded against presentments before commissioners of sewers, cases in the sheriff's turn, and a variety of base courts on matters civil and penal, dealing with disposition of property or regulatory offence. ${ }^{62}$ Rooke's Case asserted that discretion given by law "ought to be limited and bound with the rule of reason and law." 63

The machinery of executive government was very much accomplished through justices of the peace, on matters of economic legislation, licensing, labourers, the poor laws, laws of child support, and so on. ${ }^{64}$ The tools of such tribunals included binding people over to ensure attendance. So along with certiorari there evolved habeas corpus ad subjiciendum whereby people in custody could challenge the lawfulness of that fact. ${ }^{65}$

Early on, these great writs removed the cases from the inferior tribunal to the royal courts, with (in theory) the idea of them being tried there. In other words, they were more like preliminary forum motions. Had they been restricted to such a comparatively modest role, one could understand why the executive would think it wrong to use the writs to penetrate past the face documents. What would be the point? But the normative notion that the "error should be corrected" was there too.

Dr Bonham's Case (1610), 8 Co Rep 114 a at 118 a, 77 ER 646 (KB) was a decision of the Court of Common Pleas under Coke LCJ.

Lord Chancellor Egerton, Observations on The Lord Coke's Reports (London, UK: John Nutt) at 21. Henderson, supra note 46 at 89-90.

Ibid at 91 .

Rooke's Case (1598), 5 Co Rep 99 b at 100 a, 77 ER 209 (KB).

Henderson, supra note 46 at 93-94.

Ibid at 94 . 
The tendency of a legal principle to "expand itself to the limit of its logic" is rather inexorable. ${ }^{6}$ So even if Coke was rebuked, the seventeenth century saw certiorari used to settle where bakers might put their "standings" on market days and to enforce child support under bastardy laws. ${ }^{67}$ This was even before the Justices issued recognizances to be reviewed. By the mid-seventeenth century, with the paroxysm of civil war, and the effort to restrain royal discretion breaking out in violence, the emergence of divided government (executive, legislative, judicial) was becoming a reality.

Around the same time as the debate in Parliament of the Great Remonstrance and the soon thereafter attempt by Charles I to have the "Five Members" arrested in January $1642,{ }^{68}$ the case of Commins ${ }^{69}$ was before the Courts. Its processing effectively demonstrated a nearglacial strength of certiorari. The case involved a multi-year litigation over who should pay for a seawall and the opinion of the commissioners of sewers thereon. ${ }^{70}$

Although the judges involved, being Chief Justice Bramston, Justice Mallet (a royalist and former commissioner of sewers), and Justice Heath (former Attorney General), ${ }^{71}$ were surrounded (and no doubt affected) by the political turmoil, the reasons show nothing of that and calmly set forth a majority view that certiorari was applicable. ${ }^{72}$ In particular, Justice Heath, another royalist, said: "I hold that the cause is well removed by the certiorare, there is no Court whatsoever but is to be corrected by this Court: I agree that after the statute no writ of error lieth upon their proceedings, but that proves not that a certiorare lies not." ${ }^{\text {,7 }}$

Justice Heath's view was less vacillating than that of Chief Justice Bramston, and was the deciding vote in effect. The context is remarkable. Chief Justice Bramston was at the time in bad odour with the Long Parliament because he had ruled for the King on a ship's levy. He was under impeachment by Parliament when Commins was before the Court. ${ }^{74}$

Charles I revoked the patent of Chief Justice Bramston in October 1642 and installed Justice Heath in his stead. By then, Parliament was satisfied with Chief Justice Bramston and wanted him back, even under Cromwell, but he stayed out of it. For his part, Justice Heath followed Charles to Oxford in 1642. He was impeached for high treason thereafter and fled to France where he died in $1649 .^{75}$

Justice Mallet got in trouble over a petition against Parliamentary control of the militia and in favour of the Book of Common Prayer. He ended up in the Tower by Parliament order

Benjamin N Cardozo, The Nature of the Judicial Process (New Haven: Yale University Press, 1921) at 51 .

Henderson, supra note 46 at 99.

Ibid at 102 .

Commins v Massam (1642), March 196, 83 ER 473 (KB) [Commins] referred to in Henderson, supra note 46 at 101.

Henderson, ibid at 102.

Ibid at 102-104.

Ibid at 104.

Commins, supra note 69 at 197.

Henderson, supra note 46 at 103.

Ibid. 
briefly in 1642 and from 1643 to 1645 . But Justice Mallet survived the Interregnum, and was put back on the Bench by Charles II in 1660 at age $78 .^{76}$

So the human foundations of Commins were pretty shaky. But the concept stuck, although the Courts themselves were uneven in their approach to the idea, particularly as to prosecutions of the type that would be Nat Bell Liquors. ${ }^{77}$ For example, in 1670, the Conventicles Act was aimed at the suppression of disreputable preachers. ${ }^{78}$ To redouble the effort to put down this objectionable practice, Parliament sought again, as in Chapter 31, to exclude judicial review by section VI of the Conventicles Act which provided: "noe other Court whatsoever shall intermedle with any Cause or Causes of Appeale upon this Act but they shall be finally determined in the Quarter Sessions onely.",79

Perhaps assuming this did not make the point of exclusion of the King's Bench clear enough, the exclusionary perspective was fortified by section XII which added:

\begin{abstract}
That this Act, and all Clauses therein contained shall be construed most largely and beneficially for the suppressing of Conventicles and for the justification and encouragement of all persons to be employed in the execution thereof, And that noe Record, warrant or Mittimus to be made by vertue of this Act, or any proceedings thereupon shall be reversed avoided or any way impeached by reason of any defaulte in forme. ${ }^{80}$
\end{abstract}

As much as the persistence of the Conventicles Act may have pressured individuals and contributed to the populating of the United States, this enactment in the era of Charles II may have proven to be less than meets the eye. Not long after, William and Mary put in place the Bill of Rights, 1688, arguably the foundation stone of all constitutions of the modern era and the cradle of the rule of law (not to mention tripartite government as suggested by Locke). ${ }^{81}$ The same year, William and Mary also made legal history by appointing Sir John Holt as Lord Chief Justice of England.

Ibid at 104 .

Kevin Costello, “The Writ of Certiorari and Review of Summary Criminal Convictions, 1660-1848” (2012) 128 Law Q Rev 443 at 444, points out that while in the seventeenth century certiorari was establishing itself as a remedy against poor law, market regulation, and sewer commission orders, the Courts' resort to it in relation to prosecutions was less certain. While certiorari was accepted for review of convictions in Berrie's Case in 1637, Chief Justice Pemberton “almost managed to shut down the procedure entirely” in $R v$ Brigs in 1681, though he relented later. Nonetheless its use there was sparse until 1700.

1670 (UK), 22 Cha II, c 1, online: British History Online <http://www.british-history.ac.uk/report.aspx? compid=47409>.

Ibid, s VI.

Ibid, s XII.

1688 (UK), 1 Will \& Mar Sess 2, с 2 


\section{UNITED KINGDOM JUDGES SPEAK}

Though perhaps more famous for cases like Ashby, ${ }^{82}$ Chief Justice Holt also played a key role here. He helped to expand certiorari beyond the specific tribunals from which removal could occur in medieval times. ${ }^{83}$ Perhaps more importantly, he arguably commenced the process of associating the exercise of that judicial authority of certiorari with the constitutional values thus adopted by William and Mary.

For example, Chief Justice Holt spoke for judicial independence in Burwell ${ }^{84}$ so as to cut off that aspect of the older writs (that is, using the writs to condemn adjudicators). But in another ruling of Burwell he added:

Error would not lie upon the judgment, because their proceedings are not according to the course of the common law, but without indictment or forma judgment. But a certiorari lies; for no Court can be intended exempt from the superintendency of the King in this Court of King's Bench. It is a consequence of every inferior jurisdiction of record, that their proceedings be removable into this Court, to inspect the record, and see if they keep themselves within the limits of their jurisdictions. ${ }^{85}$

William Murray, 1st Earl of Mansfield, was five years old when Chief Justice Holt departed. But decades later he joined Holt in asserting with confidence the judicial role. Lord Mansfield took on the Conventicle Act in Moreley. ${ }^{86}$ Reeve and Norris had been convicted by a justice named Moneypenny for listening to a preacher named Moreley. The prosecution invoked the combination of sections 6 and 13 of the Conventicle Act to contend that "to what purpose should a certiorari issue, when the Court can neither intermeddle with the fact or form”? ${ }^{87}$ Implicitly reading the words "finally determined" in the Act to be limited to fact findings and thus not to operate such as would bar the King's Bench in reviewing matters of law or jurisdiction, Lord Mansfield asserted:

There is no colour, that these negative words should take away the jurisdiction of this Court to issue writs of certiorari. They will perhaps take away the writ of error that has been mentioned. But this Court hath an inherent power to issue certiorari's, in order to keep all Inferior Courts within due bounds, unless expressly forbid so to do, by the words of the law. If the justices have done right below, you may shew it, and quash the certiorari. But if there be the least doubt, this Court will grant the writ. ${ }^{88}$

Ashby $v$ White (1703), 1 Brown 62, 1 ER 417 (HL) [Ashby]. Other Holt classics included Coggs v Bernard (1703), 2 Ld Raym 909, 92 ER 107 (KB); Keble v Hickeringell (1707), W Kell 273, 25 ER 610 (Ch) which contributed to emergence of modern English property law and contract law, as well as the law of negligence and nuisance.

Henderson, supra note 46 at 113-16.

Groenvelt v Burwell (1700), Holt KB 394, 90 ER 1117 (KB) [Burwell]: “[N]o Judge is answerable, either to the King or the party, for mistakes or errors of his judgment, in any matters whereof he hath jurisdiction. It would expose the justice of the nation, and no man would execute the office, upon peril of being arraigned by action or indictment for every judgment he pronounces.”

Groenwelt v Burwell (1700), Holt KB 184, 90 ER 1000 (KB).

$R v$ Moreley (1760), 2 Burr 1040, 97 ER 696 (KB) [Moreley].

Ibid at 1041.

$R v$ Reeve (1760), 1 Black W 231 at 233, 96 ER 127 (KB). 
Like Chief Justice Holt before him, Lord Mansfield's approach had a double aspect: a gradual negotiation of judicial jurisdiction away from the royal power from which it was said to have arisen; and also against the royal power expressed in the legislation and appointments by which various inferior tribunals were created. But neither Holt nor Mansfield were wellpositioned to engage in an exposed and obvious power grab. Hence, their decisions (and later decisions of Chief Justices like Lord Denman) about review of decisions or exercises of jurisdiction by certiorari might be thought to have pinched down the scope of judicial review to "lack of jurisdiction." The tussle between Parliament, the executive, and the courts more clearly emerged in the nineteenth century. The outcome there very much drove the Privy Council's conclusion in Nat Bell Liquors. ${ }^{89}$

A somewhat subtle, almost inch by inch, movement had continued to broaden the scope of review up to the nineteenth century. Flagrantly using certiorari to expressly review decisions of "fact" for reasonableness does not seem to have been all that necessary. There was no official court reporting going on. So the King's Bench required justices to include within their reports what amounted to a memorandum of their decisions, usually in detail and in Latin. $^{90}$

By 1731 justices were complaining that the record required of them amounted to a summary of the trial. Costello sets out how this phenomenon emerged this way:

By the 1680 s the classical form of conviction had begun to take shape. The conviction now began with a memorandum clause, setting out the appearance of the informer: "be it remembered that ... [AB] gives the said justice of the peace to understand and be informed that one [CD] ... unlawfully did hunt a certain fallow deer."

Two significant additions to the technical form of the conviction were recognised in the last decade of the 17th century. The first concerned the contents of the witnesses' testimony. The original 17th century conviction contained the purely formal recital that the witnesses testified upon their oaths "of and upon" the "premises" (the charge as out in the summons). But there was no account of what exactly the witnesses had said. By the late 17th century a concern was circulating that this was insufficient, and that witnesses' testimony ought to be recorded. Convictions which set out precisely what prosecution witnesses had deposed appeared in the early 1680s. By the early 18th century the King's Bench confirmed that there was a positive requirement to set out the evidence.

A further set of recitals was concerned with the defendant's participation. The earlier 17th century conviction included nothing about the defendant's appearance, or about the prosecution case having been delivered in his presence. The new form, which began to became conventional in the first decade of the 18th century, required that there be a recital: (a) that the defendant had been summoned to respond "to the premises"; (b) that he had been asked to say why he should not be convicted; and (c) that the justices had "heard and understood all that the defendant had in his defence."91 
The imposition of this as a technical requirement in the convictions was tantamount to creating a method whereby the King's Bench could review the reasonableness of the conviction. As Costello points out, the statement of evidence requirement "could be used elliptically to expose misunderstandings of the criminal law."92 If the report of the justice did not cover all essentials of the actus reus, this meant a reversible error of law.

This level of review was not warmly received in all quarters. Costello said this caused Lord Sheffield in Parliament to lament that "[m]any offenders escape justice, not because they are not guilty, but because there is a word too little, or a word too much, or some technical inaccuracy in the mode of proceeding." 93

Through the eighteenth century, nervous justices found themselves required to hire lawyers to write their decisions to avoid them being quashed. ${ }^{94}$ Some tried to avoid giving reasons at all, resulting in lawyers threatening to revive the personal liability Chief Justice Holt tried to suppress in Burwell. ${ }^{95}$ Consequently, by 1848, as Lord Sumner in Nat Bell Liquors noted, error of law was readily discernible in the four corners of what the justices reported. ${ }^{96}$

Disagreement between the executive and the judiciary about the scope of the judiciary's power was not unknown across the Atlantic. The judicial department of the United States was not unreceptive to the writ of coram nobis to correct "errors of fact." 97 Article III jurisdiction, defined by Chief Justice John Marshall beginning in Marbury, ${ }^{98}$ was elaborated carefully. His work lacked universal approval. In a letter to Charles Hammond in 1821, Thomas Jefferson colourfully described how judicial power developed:

The germ of destruction of our Nation is in the power of the judiciary, an irresponsible body working like gravity by night and by day, gaining a little today and a little tomorrow and advancing its noiseless step like a thief over the field of jurisdiction until all shall render powerless the checks of one branch over the other and will become as venal and oppressive as the government from which we separated. ${ }^{99}$

At any rate, Canada inherited the law of certiorari, along with the Bill of Rights, $1688,{ }^{100}$ from the United Kingdom. So Canada inherited the cautious "bicameral” approach of Holt and Mansfield. Furthermore, even if the Conventicles Act had been snubbed, Parliament still attempted to shut out the courts, with language such as "[n]o proceedings ... shall be

Sheffield).

$94 \quad$ Ibid.

$95 \quad$ See e.g. $R$ v Dunn (1799), 8 TR 217, 101 ER 1354 (KB).

Ibid at 449 .
Ibid at 447, citing UK, HL, Parliamentary Debates, 2nd Parl, 1st Sess, vol 4 (6 June 1803) at 57 (Lord

Nat Bell Liquors, supra note 9 at 160. See $R v$ Warnford, (1825) 5 Dow \& Ry 489 at 490.

See e.g. United States v Morgan, 346 US 502 at 507 (1954) [Morgan]. See the discussion of coram nobis and its influence in the United States in United States v Denedo, 556 US 904 (2009).

Marbury v Madison, 5 US (1 Cranch) 137 (1803) [Marbury]. It should be recalled that this is a classic case of judicial review of the inaction of a government official, the then Secretary of State. It is thought by some that the language of Dr Bonham's Case (supra note 59) is in it ("that an act of the legislature, repugnant to the constitution, is void" at 177 [emphasis added]).

Cited in US, Cong Rec, vol 152, 1, at 81 (25 January 2006).

Supra note 81. 
removed into any other Court by Certiorari or otherwise." ${ }^{101}$ The age of the privative clause had begun. Moreover, Sir John Jervis brought about the Summary Jurisdiction Act, $1848^{102}$ which disposed of the requirement of elaboration of reasons and provided for a common form which did not include any statement of the evidence. As Lord Sumner noted in Nat Bell Liquors, "[t]he face of the record 'spoke' no longer: it was the inscrutable face of a sphinx." 103

Lord Chief Justice Denman suggested that Parliament correct the threads of reasoning from Holt and Mansfield when he devised what became a dominant, if arbitrarily applied, notion of logic, for judicial review. That logic was expressed in Bolton ${ }^{104}$ in these terms:

The case to be supposed is one like the present, in which the Legislature has trusted the original, it may be (as here) the final, jurisdiction on the merits to the magistrates below; in which this Court has no jurisdiction as to the merits either originally or on appeal. All that we can then do, when their decision is complained of, is to see that the case was one within their jurisdiction, and that their proceedings on the face of them are regular and according to law. Even if their decision should upon the merits be unwise or unjust, on these grounds we cannot reverse it.

Lord Denman addressed the use of affidavits to show error on the part of the justices, and suggested that even affidavits might be admitted to show lack of jurisdiction:

\begin{abstract}
But, where a charge has been well laid before a magistrate, on its face bringing itself within his jurisdiction, he is bound to commence the inquiry: in so doing he undoubtedly acts within his jurisdiction: but in the course of the enquiry, evidence being offered for and against the charge, the proper, or it may be the irresistible, conclusion to be drawn may be that the offence has not been committed, and so that the case in one sense was not within the jurisdiction. Now to receive affidavits for the purpose of shewing this is clearly in effect to shew that the magistrate's decision was wrong if he affirms the charge, and not to shew that he acted without jurisdiction: for they would admit that, in every stage of the inquiry up to the conclusion, he could not but have proceeded, and that if he had come to a different conclusion his judgment of acquittal would have been a binding judgment, and barred another proceeding for the same offence. Upon principle, therefore, affidavits cannot be received under such circumstances. The question of jurisdiction does not depend on the truth or falsehood of the charge, but upon its nature: it is determinable on the commencement, not at the conclusion, of the inquiry: and affidavits, to be receivable, must be directed to what appears at the former stage, and not to the facts disclosed in the progress of the inquiry. ${ }^{105}$
\end{abstract}

The stage was thus set for the application for certiorari brought by Nat Bell to get rather short shrift in the courts - at least on issues related to the sufficiency of the evidence supporting the conviction and the forfeiture order. But Alberta judges were not having any of that. LX; The Tweed Fisheries Act, 1857 (UK), 20 \& 21 Vict, с 148, s XCIV; The New Forest Act, 1877 (UK), 40 \& 41 Vict, c 121 , s 37. 


\section{Alberta Judges RePly}

We catch up certiorari in 1920 with an analysis of the judicial reasons in Nat Bell Liquors. As noted, Justice Hyndman was considerably less impressed with the prosecution's case than Lord Sumner. Justice Hyndman invoked Covert, ${ }^{106}$ a decision of the two-year-old Alberta Supreme Court (Appellate Division).

Covert was another man accused of an affront to the liquor statute in his operation of a “jitney bar," that is to say "a place for selling 'soft' drinks." ${ }^{107}$ Four intoxicated military men were found by police sitting in Covert's kitchen, not in the usual customer location, and with empty wine bottles. ${ }^{108}$ The soldiers told the police they brought the liquor with them. They then shipped out with their battalion and were not available as witnesses. Covert asserted he did not permit liquor consumption nor sell liquor in his place. The magistrate thought otherwise. Again there was no appeal, so the route was certiorari.

In Covert, Justice Beck (with the concurrence of Justices Hyndman and Scott ${ }^{109}$ ) opined that on certiorari, the Court should have some regard to the alleged supporting evidence, remarking, "[t]he duty of the Court is not to weigh conflicting evidence but, while being careful not to do so, is to see that the accused has been convicted only upon legal and sufficient evidence." 110 Justice Beck found the prompt assertions of the soldiers rather compelling. He added, "[t]o permit a trial Judge to refuse to accept evidence given under all these conditions would be to permit him to determine the dispute arbitrarily and in disregard of the evidence, which is surely not the spirit of our system of jurisprudence.”111

Justice Hyndman acknowledged the 200 pages of transcript of evidence in Nat Bell Liquors but to him, the case came to this:

\footnotetext{
Now, it is clear there is no contradiction of the sale by Angel to Bolsing; no witness denies that. Angel himself admits it but says in effect that he sold this case of whisky without the knowledge or authority of his principals and against their general instructions and put the money in his own pocket; that neither Bell nor Sugarman knew anything whatever about it. He maintains throughout that no liquor was ever permitted to go out of the warehouse except for export purposes. The principals both stoutly deny any knowledge of the transaction whatsoever. They admit seeing Bolsing in the building but deny they had any knowledge whatsoever of his dealings with Angel; that they overheard and saw nothing which took place between them. This latter fact is admitted by Bolsing himself, and all the surrounding circumstances appearing in the evidence for the prosecution tend to confirm that fact.
}

$R v$ Covert (1916), 10 Alta LR 349 (SC (AD)) [Covert]. The panel was Justices Scott, Stuart, Beck, and Hyndman. Ibid at 358.

Ibid at 363-64.

Scott's dispute with Harvey as to who was Chief Justice was not settled yet. See Mittelstadt, supra note 42 at 108-109.

Covert, supra note 106 at 363.

Ibid at 364. Interestingly, Justice Stuart who dissented in Covert explained his view in a manner which also weighed the evidence — just more skeptically. 
Every action and movement made by the two guilty parties would give the impression that what they did was intended to be, and in fact was, in secret and without the knowledge of other parties. These circumstances must surely be taken into account as corroborative of the flat denials of Sugarman and Bell. ${ }^{112}$

Justice Hyndman duly noted that the magistrate in his "summing-up” had said, "I consider the evidence of the defendant's witnesses evasive and points were at variance.” To which Justice Hyndman responded, “[j]ust what particular part or parts of the evidence the magistrate had in mind does not appear and I think he should have given reasons for this conclusion.”"113

For himself, Justice Hyndman saw no basis for this, nor for dismissing the stenographer's exculpating evidence. Beyond this, Justice Hyndman found no reasonable basis for the ballooning of the case from a single illegal sale to a "keeping" charge which exposed the entire warehouse. He found no evidence whatsoever that this large and open export business was a "a device, cover or subterfuge for illicit local traffic."114

The majority of the Appellate Division in Nat Bell Liquors similarly dismissed the prosecution's case. Chief Justice Harvey, dissenting, found "there was, in my opinion, evidence upon which the magistrate could convict” and for that matter he could condemn the entire whiskey supply. ${ }^{115}$

For his part, Justice Stuart noted that "three or four detectives" of the provincial police had been assigned to the task of discovering whether the company was violating the Act. ${ }^{116}$ The magistrate "who is not a lawyer by profession" had not only convicted and fined \$200, but ordered the huge forfeiture. ${ }^{117}$ Perspicaciously, Justice Stuart expressed some concern about "the peculiar situation of the law by which the Crown through its officers may ask a man to commit a breach of the law, indeed actually persuade him to do it and then complain against him in a Criminal Court for having done so and have him fined. There seems to be no law forbidding this method of detecting crime and it may be necessary that it should be permissible."118

Justice Stuart was able to use this consideration to assert that there should have been caution about Bolsing's evidence. Justice Stuart noted where Bolsing was caught in misleading or false evidence, and how elsewhere there was "some evasiveness easily discernible." 119 Justice Stuart added, "[a]fter reading the reasons the justice gave for convicting, I cannot discover that he kept in mind, as he should have kept in mind, his duty to receive a spy's evidence with caution or that he even remembered the untruths in the spy's evidence to which I have referred."

Ibid.

Ibid at 154 .

Nat Bell Liquors (AD), supra note 22 at 158.

Ibid at 167.

Ibid.

Ibid at 168 .

Ibid at 169 .

Ibid. 
Stuart took the view that it was not an "appeal on the facts to say that the magistrate misdirected himself in his duty as a judicial officer in failing to take into account the true character of the evidence of the prosecution on a crucial point." ${ }^{121}$ He also found no sufficient basis to expand the single selling act to a tainted keeping of the entire stock.

Justice Beck, concurring, also endorsed the conclusion of Justice Hyndman with an extensive analysis of how certiorari supported intervention here. Justice Beck added "[a] sense of injustice pervades the case throughout and a pretence of unusual fairness in the argument before the magistrate on behalf of the Crown.... I cannot believe that the AttorneyGeneral of the province, if he informs himself fully concerning the matter, will permit so gross an injustice as the company has been subject to be further magnified."122

Justice Beck was mistaken. The Attorney General turned out to be quite prepared to send counsel to board a ship to England to scuttle the appellate division judgment nine years after the sinking of the RMS Titanic. Of course, Nat Bell's counsel went too.

\section{PRIVY COUNCIL TRIES TO CLOSE THE DOOR}

Arrayed before the Privy Council (consisting of Lords Buckmaster, Atkinson, Sumner, Wrenbury, and Carson) in Nat Bell Liquors were eminent (and out of the ordinary) lawyers. Charles Coursolles McCaul and his junior, Denis Nowell Pritt, acted for the company. Sidney Brown Woods and an English barrister, Geoffrey Lawrence, appeared for the appellant Attorney General of Alberta.

McCaul $^{123}$ was formidable in appearance, but evidently quite sociable in manner. He also had a restless spirit, and travelled widely. He never stayed in many law firms for long, and was associated with many of the major legal figures of his era, at different times. He was also a respected author on topics as varied as the law of vendor and purchaser (with one of his partners, George C. Valens), as well as work on climate, geology, and history of the region. He was even an amateur thespian and sketch artist at times. ${ }^{124}$ He went to Dawson City in the midst of the Klondike Gold Rush, and spent his diary time writing about social affairs, mining, and engineering.

Ibid.

Ibid at 188 .

McCaul's broad resume included appearing for the prosecution in major cases, such as the case of one Sinnisiak for murder of RP Rouviere, at Bloody Fall on the Coppermine River in November 1913 (see Edwin R Keedy, “A Remarkable Murder Trial: Rex v Sinnisiak” (1951) 100:1 U Pa L Rev 48). That trial went before Chief Justice Harvey and a jury, at Edmonton commencing on 14 August 1917. Twenty years earlier, he and Harvey had produced a guide to the ordinances of the Northwest Territories. See Louis A Knafla, “McCaul, Charles Coursolles” Dictionary of Canadian Biography, vol 15 (Toronto: University of Toronto, 2005), online: Dictionary of Canadian Biographies < http://www.biographi.ca/en/ bio/mccaul_charles_coursolles_15E.html>.

McCaul also accidentally shot himself in the chest on 23 June 1887 while cleaning his gun. His life was saved by Dr George Allan Kennedy, the first North West Mounted Police physician to come to Alberta. See “Dr. George Allan Kennedy, 1858-1913,” online: Alberta Medical Association < http://www.alberta doctors.org/about/medical-history/patients-1st-for-over-100-years/Kennedy>. 
Pritt was another quite noteworthy character. ${ }^{125}$ A member of the Labour Party from 1918, he was a defender of the Soviet Union under Joseph Stalin. In 1932, as part of G.D.H. Cole’s New Fabian Research Bureau's “expert commission of enquiry,” he visited the Soviet Union. According to Margaret Cole "the eminent KC swallow[ed] it all."126 George Orwell apparently referred to the prolific writer as "perhaps the most effective pro-Soviet publicist in this country," a role he played right up to the era of the Vietnam War. ${ }^{127}$ Pritt represented a remarkable clientele. ${ }^{128}$

Woods was a founding partner of the Alberta law firm, Woods, Sherry, Collison, and Field which became, at one stage, Field Atkinson Perraton on a major merger, and most recently, Field Law. In a way, Woods was Alberta. Like McCaul, a man seemingly out of central casting, he was the first Deputy Attorney General of Alberta, having been in the new province from 1906 to 1910. Justice John W. McClung wrote of him that he was "an unyielding and demanding counsel" but that he gave generously of himself to the University of Alberta, the Law Society, and the Canadian Bar Association. ${ }^{129}$ Woods appeared before the Privy Council on a number of significant cases, ${ }^{130}$ including one where, according to Justice McClung, the Chairman of the Board asked him, "Before you commence Mr. Woods, would you please tell us precisely where Alberta is to be found?"131

Geoffrey Lawrence, third Baron Trevethin, later first Baron Oaksey, went on to become the lead British Judge during the Nuremberg trials following the Second World War, and President of the Judicial group for that body (having been elected to the role). ${ }^{132}$ He was made a Lord Justice of Appeal in 1944. At the time of Nat Bell Liquors, his father, Alfred T. Lawrence, first Baron Trevethin, was briefly Lord Chief Justice of England. ${ }^{133}$ Lawrence,

See Kevin Morgan, "Pritt, Denis Nowell (1887-1972)," Oxford Dictionary of National Biography (Oxford: Oxford University Press, 2004); “Denis Pritt,” online: Wikipedia <http://en.wikipedia.org/w/ index.php?title-Denis_Pritt\&oldid=616208349>.

Letter to GDH Cole cited in Kevin Morgan, The Webbs and Soviet Communism: Bolshevism and the British Left, vol 2 (London: Lawrence \& Wishart, 2006) at 177 [emphasis in original].

George Orwell, As I Please: 1943-1945, Sonia Orwell \& Ian Angus, eds (New York: Harcourt, Brace \& World, 1968) at 192.

See e.g. Ho Chi Minh in 1931-32 against a French request for his extradition from Hong Kong (Pierre Brocheux, Ho Chi Minh: A Biography, translated by Claire Duiker (Cambridge: Cambridge University Press, 2007) at 55). Also the Kapenguria Six, a group of Kenyan political figures accused in 1952 of Mau Mau links (Caroline Elkins, Imperial Reckoning: The Untold Story of Britain's Gulag in Kenya (New York: Henry Holt, 2005) at 40).

Contained in an inscription by the Honourable Justice JW McClung late of the Court of Appeal which he affixed to a photograph of Woods in a photo gallery in the judicial corridors of the Edmonton Law Courts Building.

For example: Northwestern Utilities Ltd v London Guarantee \& Accident Co (1935), [1936] AC 108 (PC) (as to the rule in Rylands v Fletcher); McPherson v McPherson (1935), [1936] AC 177 (PC) (a divorce granted in a judge's library with no public access is voidable as contrary to the open court principle).

Supra note 129.

See RFV Heuston, “Lawrence, Geoffrey, third Baron Trevethin and first Baron Oaksey (1880-1971)," Oxford Dictionary of National Biography (Oxford: Oxford University Press, 2004).

Succeeding the Earl of Reading and followed by Lord Gordon Hewart. Alfred T Lawrence had been given the position by David Lloyd George but executed an undated letter of resignation as he knew he was filling in until Hewart was eligible. A story of the era has it that he read about his resignation in a newspaper while on a train to London. NG Davidson, "Lawrence, Alfred Tristram, first Baron Trevethin (1843-1936),” rev Robert Stevens, Oxford Dictionary of National Biography (Oxford: Oxford University Press, 2004). 
of the Inner Temple since 1906, was a decorated (DSO) veteran of the First World War when he appeared with Woods. As Lord Oaksey, he was a Lord of Appeal in Ordinary, and also himself a member of the Privy Council from 1947 to 1957.

Since 2009, the chamber where the Judicial Committee of the Privy Council ${ }^{134}$ conducts itself as a Board is Middlesex Guildhall in Westminster. It was previously at Downing Street. ${ }^{135}$ By tradition, the members, dressed in suits, would assemble in the Board room after everyone was cleared out, and then counsel and others would be allowed in. The decisions of the Privy Council were advice to the Crown, but the sovereign acted on that advice.

The Privy Council in 1920 was well satisfied that the Alberta judges had adopted a basis for a grant of certiorari that simply did not sit with the established limits of application of that writ. The Alberta judges had weighed the sufficiency of the case, and, as Lord Sumner wrote, "[o]n certiorari, so far as the presence or absence of evidence becomes material, the question can at most be whether any evidence at all was given on the essential point referred to. Its weight is entirely for the inferior Court." 136

Lord Sumner noted a range of opinion in the provinces of Canada on whether absence of evidence of a particular element of an offence went to jurisdiction but that certiorari was nonetheless not applied to weigh the strength of the case. He explored cases which suggested that deciding despite a complete void of an essential ingredient in the case was still a matter within jurisdiction and not an excess of jurisdiction such as to give rise to certiorari. Tracing this line of authority led Lord Sumner to Bolton and the views of Lord Denman. ${ }^{137}$

Lord Sumner asserted that the "law laid down in Reg. v. Bolton has never since been seriously disputed in England." "138 Interestingly, Lord Sumner chose to add that there was no difference between civil or criminal law in this respect, thus in a sideways manner contributing to the oncoming consolidation of principles of judicial review:

There is no reason to suppose that, if there were any difference in the rules as to the examination of the evidence below on certiorari before a superior Court, it would be a difference in favour of examining it in criminal matters, when it would not be examined in civil matters, but, truly speaking, the whole theory of certiorari shows that no such difference exists. The object is to examine the proceedings in the inferior Court to see whether its order has been made within its jurisdiction. If that is the whole object, there can be no difference for this purpose between civil orders and criminal convictions, except in so far as differences in the form of the record of the inferior Court's determination or in the statute law relating to the matter may

At the time of the Tudors, the Privy Council was a group of trusted advisors of Henry VIII and Elizabeth I, and almost a legislative body. In 1833 its judicial character was formalized. See FW Maitland, The Constitutional History of England (Cambridge: Cambridge University Press, 1908) at 251-56, 462-63. "Sites," online: Judicial Committee of the Privy Council <http://www.jcpc.uk/about/sites.html>. Nat Bell Liquors, supra note 9 at 144. Ibid at 153; Bolton, supra note 104.

Nat Bell Liquors, ibid at 154 [footnotes omitted]. This is an interesting statement when one notes, for example, that in Colonial Bank of Australasia $v$ Willan (1874), LR 5 PC 417 at 442-45, the Privy Council had offered opinion about what sort of "defect of jurisdiction” might justify resort to certiorari, albeit largely in dicta. Similarly, in Walsall (Overseers of) v London \& North Western Railway Company (1878), 4 AC 30 (PC), error of law on the face of the record was considered a sufficient ground for certiorari. 
give an opportunity for detecting error on the record in one case, which in another would not have been apparent to the superior Court, and therefore would not have been available as a reason for quashing the proceedings. $^{139}$

Lord Sumner found a misapprehension of English authority at the bottom of the Alberta judges' opinion. ${ }^{140}$ As to the Alberta judges' error, Lord Sumner ventured comment which added to the torment of the law of judicial review for decades to follow. He said the Alberta judges misunderstood earlier Privy Council opinion "probably due to the not infrequent confusion between facts essential to the existence of jurisdiction in the inferior Court which it is within the competence of that Court to inquire into and to determine, and facts essential thereto which are only within the competence of the superior Court."

Moreover, Lord Sumner opined that the Alberta judges had erred in not feeling constrained by the Summary Jurisdiction Act, 1848, ${ }^{142}$ and holding that while the Act limited the practical availability of certiorari in the mother country, it had no such effect in Alberta. Alberta judges felt they could reach back past the Act for a more robust review. Lord Sumner stamped down hard on that point of view:

Reg. v. Bolton, undoubtedly, is a landmark in the history of certiorari, for it summarises in an impeccable form the principles of its application under the régime created by what are called Jervis's Acts, but it did not change, nor did those Acts change the general law. When the Summary Jurisdiction Act provided, as the sufficient record of all summary convictions, a common form, which did not include any statement of the evidence for the conviction, it did not stint the jurisdiction of the Queen's Bench, or alter the actual law of certiorari. What it did was to disarm its exercise. The effect was not to make that which had been error, error no longer, but to remove nearly all opportunity for its detection. The face of the record "spoke" no longer: it was the inscrutable face of a sphinx. ${ }^{143}$

Long before Jervis's Acts statutes had been passed which created an inferior Court, and declared its decisions to be "final” and “without appeal," and again and again the Court of King's Bench had held that language of this kind did not restrict or take away the right of the Court to bring the proceedings before itself by certiorari. There is no need to regard this as a conflict between the Court and Parliament; on the contrary, the latter, by continuing to use the same language in subsequent enactments, accepted this interpretation, which is now clearly established and is applicable to Canadian legislation, both Dominion and Provincial, when regulating the rights of certiorari and of appeal in similar terms. The Summary Jurisdiction Act, 1848, was intended to produce and did produce its result by a simple change in procedure without unduly ousting the supervisory jurisdiction of the superior Court. ${ }^{144}$

Nat Bell Liquors, ibid at 154-55.

Ibid at 156.

Ibid at 158 .

Supra note 102.

Nat Bell Liquors, supra note 9 at 159 [footnotes omitted]. The case as reported in $R v$ Nat Bell Liquors Ltd (1922), 65 DLR 1 at 25 (PC) [Nat Bell Liquors (DLR)], includes the following additional sentence at this point: "Efforts have indeed been made to avoid this result by purporting to question the jurisdiction of the Court below, while really inquiring into its exercise, thus bringing before the superior Court, otherwise than on the record itself, matters which ought to be before it on the record or not at all, but these efforts have been made under some confusion of thought."

Nat Bell Liquors, supra note 9 at 159-60. 
Lord Sumner said "there is not one law of certiorari before 1848 and another after it, nor one law of certiorari for England and another for Canada.”145 To him, only competent legislation could change the situation. Some privative-like clause language in sections 62 and 63 of The Liquor Act attracted comment by him, but led nowhere. ${ }^{146}$ In sum:

\footnotetext{
Their Lordships are of opinion that the provisions of the Canadian Criminal Code and of the Alberta Liquor Act have not the effect of undoing the consequences of the enactment of a general form of conviction; that the evidence, thus forming no part of the record, is not available material on which the superior Court can enter on an examination of the proceedings below for the purpose of quashing the conviction, the jurisdiction of the magistrate having been once established, and that it is not competent to the superior Court, under the guise of examining whether such jurisdiction was established, to consider whether or not some evidence was forthcoming before the magistrate of every fact which had to be sworn to in order to render a conviction a right exercise of his jurisdiction. ${ }^{147}$
}

In other words, despite being aware that the Summary Jurisdiction Act, 1848 and comparable laws of Canada had created a situation where errors of law were no longer detectable, thus potentially denying justice, Lord Sumner said both the conviction and the forfeiture order withstood claims of "no evidence." No other legal defects destroyed either disposition in Nat Bell Liquors.

Despite this, later interpretations of what Lord Sumner said would have surprised him. The Privy Council's starved view of certiorari for only jurisdictional error did not last. Even before Nat Bell Liquors there were other voices that disputed the benefits of such a hands-off attitude towards extensions of the executive.

Lord Justice Farwell in Dyson scathingly said that "[i]f ministerial responsibility were more than the mere shadow of a name" then it might see tribunals of the executive reviewed in Parliament; but, as it was, "the Courts are the only defence of the liberty of the subject against departmental aggression.”148

Whether jurisdictional error arose because "on some part of the case, which was material to the charge and had to be legitimately established before the accused person could be convicted, no evidence was forthcoming at all" was not entirely clear after Nat Bell Liquors. ${ }^{149}$ Lord Sumner considered cases of "no evidence" to be a rare occurrence notably because they would require the reviewing superior court to examine the entire record.

Rare or not, this zone of jurisdiction to intervene by certiorari was hardly scotched. It became well established in the criminal law of Canada. The Supreme Court held in Skogman that both breach of principles of natural justice and excess of the assigned statutory

\footnotetext{
$145 \quad$ Ibid at 161.

146 Ibid at 163-65; The Liquor Act, supra note 10, ss 62-63.

$147 \quad$ Ibid at 165.

148 Dyson v AG (1910), [1911] 1 KB 410 (CA) at 424 [Dyson].

$149 \quad$ Nat Bell Liquors, supra note 9 at 149.
} 
jurisdiction by acting on "no evidence" was jurisdictional error to justify certiorari. ${ }^{150} \mathrm{Nat}$ Bell Liquors was cited in Skogman, as it had been in Patterson. ${ }^{151}$

The Appellate Division, not long after Nat Bell Liquors, had advanced the "natural justice" point as a jurisdictional basis for intervention by certiorari in Solloway. ${ }^{152}$ Solloway was a case impugning an order to stand trial after a preliminary inquiry, but there the principal objection was the denial of a right to challenge the prosecution's evidence at that stage.

Solloway was mentioned approvingly by Justice Spence in dissent in Patterson. ${ }^{153}$ The majority in Patterson felt there was not a denial of natural justice in actuality, so it did not quite reach what Justice Spence said. But Justice Hall, in a concurrence to the outcome, agreed with Justice Spence on the principle, and drew from Lord Sumner's judgment in Nat Bell Liquors when Justice Hall wrote,

\begin{abstract}
I am unable to accede to the view that an accused or counsel for an accused at a preliminary hearing is under no circumstances entitled to production of statements given by witnesses for the prosecution who are then being cross-examined. It is my view that if production of a statement made by a witness then under cross-examination at a preliminary hearing is shown to be essential to the full exercise of the right to cross-examine, then a refusal to order production could result in a denial of natural justice, and such a denial would, within the language of Lord Sumner ... be a failure in the observance of the law in the course of exercising jurisdiction, but that was not the situation here. ${ }^{154}$
\end{abstract}

This comment of Justice Hall might have faded away as a single judge concurrence, but for its adoption, albeit in obiter, by a five-member division of the Ontario Court of Appeal in Martin. ${ }^{155}$ The decision in Martin was itself upheld by the Supreme Court, albeit as a result of characterizing the appeal as moot. ${ }^{156}$

By the time the Supreme Court was in a position to address the point directly in Forsythe, ${ }^{157}$ it was persuaded that a breach of natural justice could constitute a jurisdictional defect in the decision of a judge at a preliminary inquiry and therefore justify certiorari. In turn, Forsythe and Martin were directly cited in Skogman for the proposition that

See $R v$ Skogman, [1984] 2 SCR 93 at 99, 100, 108 [Skogman]. The stringency of the review for jurisdictional defect was reminiscent of Lord Sumner's view of rarity, as it was held to be sufficient to fall within the jurisdiction of a provincial Court at a preliminary inquiry to commit the accused to trial as long as "there was a scintilla of evidence to support the committal of the appellant to trial" (ibid at 108). See also $R v$ Russell, 2001 SCC 53, [2001] 2 SCR 804 at paras 19-21. Skogman, ibid at 101, 117-18; $R$ v Patterson, [1970] SCR 409 at 413 [Patterson] (also a case out of Alberta).

$R v$ Solloway; $R v$ Mills (1930), 24 Alta LR 404 at 406 (SC (AD)) [Solloway] where Chief Justice Harvey wrote that "the defence ought to be given a fair chance by cross-examination of Crown witnesses or production of evidence to show, if it can, that what might otherwise appear to be a prima-facie case of guilt should have an innocent construction placed upon it." See also the discussion of $R v$ Picariello (1922), 18 Alta LR 338 (SC (AD)) [Picariello], in Part VIII, below. Patterson, supra note 151 at 418-19.

Ibid at 414.

Re Martin, Simard and Desjardins and the Queen (1978), 20 OR (2d) 455 (CA) [Martin].

Martin $v$ The Queen, [1978] 2 SCR 511 at 515.

Forsythe $v$ The Queen, [1980] 2 SCR 268 [Forsythe]. 
jurisdictional error was necessary to upset an order to stand trial, and that the complete absence of evidence or a significant breach of natural justice would go to jurisdiction. ${ }^{158}$

In other words, Lord Sumner's view about the rarity of intervention by certiorari against decisions of criminal or penal tribunals was later taken more for its recognition of review for lack of jurisdiction than as a negation of the role of certiorari.

The scope of jurisdictional defect became a touchstone for the application of certiorari to the criminal law, much as it had taken on power in administrative law. Lord Sumner's suggestion of overlap in civil and criminal law also became something of a tailwind for judicial review for both.

\section{THE HORNS OF JURISDICTION BY THE MID-TWENTIETH CENTURY}

A lot of water passed under the bridge from the time when Coke and Holt suggested a constitutional dimension to judicial review, to the period when the contributions of Lord Denman and the Privy Council in Nat Bell Liquors seemed to put quietus to such an idea. If they meant to extinguish certiorari, the latter did not succeed. They left alive facial jurisdictional error in its application, plus other observations extracted from the Nat Bell Liquors obiter. Lord Denman's view was akin to Dicey's in acceptance of Parliamentary crimp.

Indeed, one lawyer, D.M. Gordon, crowed about Alberta Courts getting their comeuppance even decades later. Gordon wrote in 1953 that Nat Bell Liquors involved a "momentary revolt ... which in Alberta proved short-lived. This was no small satisfaction to those who felt concerned with the rational development of the law; they had seen that zeal to remedy hard cases could be carried too far."159

In his dismissive view, interventions were based on "sophistries pursued in the older decisions that tried to make nearly every serious procedural error go to jurisdiction." 160 There "must be special circumstances to magnify" error into jurisdiction. ${ }^{161}$ He hinted that it was self-indulgent for courts to consider the reasonableness of anything under certiorari, referring to "[a]ttempts to enlarge the class of errors that could be attacked on certiorari."162

In particular, Gordon chastised Justice Gale (as he then was) for his reliance on "the case of Rex $v$ Picariello, which most of us would have preferred to see remain buried in

Skogman, supra note 150 at 101-104.

DM Gordon, Case and Comment on Toronto Newspaper Guild v Globe Printing Co, [1953] 2 SCR 18 (1953) 31:10 Can Bar Rev 1158 at 1160.

Ibid at 1162 .

Ibid.

Ibid at 1160 . 
oblivion.” ${ }^{163}$ Picariello ${ }^{164}$ was interesting in various ways. ${ }^{165}$ A divided five-member panel of the Appellate Division got rather "in the face” of the Privy Council.

Justice Stuart, though dissenting in the result and finding that certiorari was not justified against a magistrate's denial of an adjournment, expressed some puzzlement as to aspects of Lord Sumner's decision:

\begin{abstract}
Surely however we may still venture in this Court to enquire whether the inferior Court has or has not refused an accused the right to make his full answer and defence to the charge even though the magistrate has not inserted the facts relevant thereto in the formal conviction. For myself I do not feel that we should be doing right to allow anything which was said in the Nat Bell Case (and possibly nothing there said was so intended) to prevent us from making this enquiry and that too upon any evidence or material that we may think in our judgment to be relevant and proper. I propose therefore to look at the stenographic report, at the affidavit made by the accused and at the special note signed by the magistrate relating to what really occurred. I refuse however to resort to the subterfuge that this is a matter of jurisdiction, as I did refuse in Rex v. Emery, 10 Alta. L.R. 139 with regard to the absence of evidence. ${ }^{166}$
\end{abstract}

Justice Beck, concurring with the majority that certiorari did lie against the magistrate for refusal of the adjournment, added "I shall on some future occasion make some observations upon the decision of the Privy Council in Rex v. Nat Bell Liquors Ltd... Having examined the evidence it seems clear enough that so far as it was permitted to be given, the evidence would be sufficient to justify a conviction."167

Justice Hyndman and Chief Justice Scott conceded that "when the appeal came on before us it was recognized that in view of the judgment just mentioned it was not competent for us to examine the evidence for the purpose of ascertaining whether or not there was any or sufficient evidence upon which a conviction should have been made.”168 But there was a denial of the right to make full answer and defence in the denial of an adjournment. Justice Clarke declined to express an opinion about the availability of certiorari. ${ }^{169}$

Despite the perfervid views of Gordon and others, the stilling, let alone interment, of certiorari did not happen with Nat Bell Liquors. Gordon tried to use it to recast the meaning

Ibid [footnotes omitted].

Picariello, supra note 152.

One of those ways is that the events occurred on 11 January 1922 with the arrival of liquor smuggled from Fernie, British Columbia into the Crows Nest Pass community of Blairmore, where the accused was known as "Emperor Pic, the Bottle King" and was an infamous bootlegger. About 7:15 in the evening of 21 September 1922, Constable Lawson of the Alberta Provincial Police, engaged in further efforts to impede Picariello's activities, was shot in the back by either Picariello or his girlfriend Florence Lassandro, resulting in his death a few minutes afterwards. See generally Brian Brennan, Scoundrels and Scallywags: Characters from Alberta's Past (Calgary: Fifth House, 2002) at 51-63. Both were convicted of capital murder, and their convictions were sustained on appeal to the Appellate Division on 12 February 1923: $R v$ Picariello and Lassandro (1923), 19 Alta LR 177 (SC (AD)). Stuart, Beck, and Hyndman were three of the five presiding judges. Both were hanged, Lassandro being the last woman to be executed in Canada.

Picariello, supra note 152 at 341-42.

Ibid at 344 .

Ibid at 345 .

Ibid at 352. 
both of a (then recent) decision of the Supreme Court in Globe Printing, ${ }^{170}$ and a House of Lords decision in Spackman. ${ }^{171}$ Neither really supported Gordon's wish for exclusion of certiorari.

Gordon blew off Spackman as a case where the Lords, other than Lord Wright, never really discussed certiorari. ${ }^{172}$ However, the case was certiorari as to the improper exclusion of evidence. That the parties never objected to certiorari was more telling than Gordon suggested. For its part, Globe Printing involved a privative clause that read:

Subject to such right of appeal as may be provided by the regulations, the orders, decisions and rulings of the Board shall be final and shall not be questioned or reviewed nor shall any proceeding before the Board be removed, nor shall the Board be restrained, by injunction, prohibition, mandamus, quo warranto, certiorari or otherwise by any court, but the Board may, if it considers it advisable to do so, reconsider any decision or order made by it and may vary or revoke any such decision or order. ${ }^{173}$

Certiorari had nonetheless been granted to quash a decision of a labour board to accept a union for certification.

Justice Kerwin for the majority in Globe Printing noted a decision called Marsham where Lord Chancellor Halsbury stated that "the act of the magistrate was not a mere rejection of evidence, but amounted to a declining to enter upon an inquiry on which he was bound to enter.” ${ }^{\prime 74}$ Lord Esher explained a distinction between refusing evidence as error within jurisdiction, and refusing evidence as error amounting to refusing jurisdiction. ${ }^{175}$ Justice Kerwin added,

Lord Esher's judgment, I think, sets forth the test to determine whether there be, in any particular case, a mere rejection of evidence or a refusal of jurisdiction. There is nothing inconsistent in it and the judgment of the Judicial Committee in Rex v. Nat Bell Liquors; but I might point out two things in connection with the latter. When the occasion arises, it may be necessary to read it in the light of the judgment of Lord Goddard, speaking on behalf of the King's Bench Division in Rex v. Northumberland Compensation Appeal Tribunal, affirmed by the Court of Appeal; and that we are not concerned with the applicability of the Nat Bell judgment to a motion "to quash a conviction, order, warrant or inquisition" as those words are used in s. 65 of the Ontario Judicature Act, R.S.O. 1950, c. $190 .^{176}$

Justice Kerwin went on to file Nat Bell Liquors in the "limited resort” cabinet, and to add that,

[s]ections similar to s. 5 of [The Labour Relations Act], although differing in form, have been enacted by legislative bodies from time to time but it is unnecessary to set forth the decisions in which they have been

Toronto Newspaper Guild, Local 87, American Newspaper Guild (CIO) v Globe Printing Company, [1953] 2 SCR 18 [Globe Printing]. General Medical Council v Spackman, [1943] AC 627 (HL) [Spackman]. Gordon, supra note 159 at 1161.

The Labour Relations Act, 1948, SO 1948, c 51, s 5 cited in Globe Printing, supra note 170 at 21. $R v$ Marsham (1891), [1892] 1 QB 371 at 375 (CA) [Marsham]. Ibid at 378.

Globe Printing, supra note 170 at 24 [footnotes omitted]. 
considered because, if jurisdiction has been exceeded, such a section cannot avail to protect an order of the Board; and I understood that to be conceded by counsel for the appellant. Since in my view the Board exceeded its jurisdiction, s. 4 of the Act, also relied upon by counsel for the appellant, does not assist him. Finally, it is stated in the Board's reasons, which I hold to be a part of the return, that the Board "further finds on the basis of the documentary evidence submitted by the parties.” There is nothing to justify the suggestion that the Board, or any member thereof, was even purporting to act under the provisions of s-s. 7 or 8 of s. 3 , or that they had any evidence other than the Union records placed before it by the appellant. ${ }^{177}$

The reference in Globe Printing to Northumberland ${ }^{178}$ is also important. There, Lord Singleton drew from the assertion in Nat Bell Liquors that the Summary Jurisdiction Act, 1848 made "no alteration in the law as to certiorari." 179 To him, that meant "certiorari will lie if there be error on the face of the proceedings." ${ }^{.180}$ Lord Justice Singleton noted Spackman, which, though said to be a "natural justice" argument, "might have been said to depend on the true construction of section 29 of the Medical Act, 1858."181

Lord Denning, concurring, surveyed something of the history of certiorari. He noted its "amplitude," and its purpose to have the inferior court record "sent up so that the King's Bench may cause to be done thereon "what of right and according to the law and custom of England' ought to be done."182 Reminiscing on the "days of Holt C.J.," Lord Justice Denning nodded to Nat Bell Liquors, saying that the scope of certiorari had been "somewhat forgotten" thereafter, but wrongly so. ${ }^{183}$ In his research, certiorari was "used to correct errors of law which appear on the face of the record, even though they do not go to jurisdiction." 184 He also seized on the comment in Nat Bell Liquors that the fundamental principles of certiorari remained untouched despite the 1848 statute. ${ }^{185}$

After panning his judicial lens over criminal cases since Holt, Lord Justice Denning turned to authorities affecting statutory tribunals. One of those involved a body of commissioners which refused to obey certiorari, with the result that "the whole body of them were 'laid by the heels. ${ }^{\prime \prime 186}$ He also mentioned Commins from $1642 .{ }^{187}$ Lord Justice Denning did say that affidavit evidence was not, in principle, admissible for error of law on the face but various cases, including Spackman, circumnavigated that limitation. ${ }^{188}$ He said that even statutory limits could be bypassed by consent. ${ }^{189}$ In the case at bar there was a plain error and that was enough to justify certiorari.

Ibid at 26.

$R v$ Northumberland Compensation Appeal Tribunal (1951), [1952] 1 KB 338 (CA) [Northumberland]. Ibid at 343; supra note 102.

Northumberland, ibid.

Ibid at 345 .

Ibid at 347.

Ibid at 348 .

Ibid.

Ibid at 349.

Ibid at 350 .

Ibid at 351 (sub nom Cummins v Massam); Commins, supra note 69.

Northumberland, supra note 178 at 353.

Ibid. 
Lord Justice Morris in Northumberland also said that certiorari was not just appeal disguised, but it did apply to error of law on the face of the record and to lack or excess of jurisdiction. ${ }^{190}$ Lord Justice Denning was soon thereafter also able to dispose of a privative clause applicable to the review of a decision of a medical appeal tribunal in Gilmore. ${ }^{191}$

The clause in Gilmore said the decision was to be "final"; that was "not enough" to oust certiorari for excess of jurisdiction or error of law on the face of the record. ${ }^{192}$ Lord Justice Denning reached back, this time to Coke, and again to Holt and Mansfield. In his view, language in Nat Bell Liquors left intact the train of reasoning which bypassed privative language from 1680 to $1848 .{ }^{193}$ For lack of jurisdiction cases, such clauses had no effect. For error of law on the face, they had no effect because, properly interpreted, they did not deal with certiorari.

Before moving on, it is pertinent to note the watershed case of Wednesbury, ${ }^{194}$ which was of a similar vintage to Northumberland. This was a declaration case: an authority that has since been folded into judicial review along with the ancient writs. Wednesbury was a licensing case, essentially dealing with whether a movie house could be allowed to open on a Sunday. The borough council had set conditions, and the review was of the discretion to set those conditions. This resulted in a classic statement of the meaning of reasonableness in discretion exercised by the executive:

\footnotetext{
It is true the discretion must be exercised reasonably. Now what does that mean? Lawyers familiar with the phraseology commonly used in relation to the exercise of statutory discretions often use the word "unreasonable" in a rather comprehensive sense. It has frequently been used and is frequently used as a general description of the things that must not be done. For instance, a person entrusted with a discretion must, so to speak, direct himself properly in law. He must call his own attention to the matters which he is bound to consider. He must exclude from his consideration matters which are irrelevant to what he has to consider. If he does not obey those rules, he may truly be said, and often is said, to be acting "unreasonably." Similarly, there may be something so absurd that no sensible person could ever dream that it lay within the powers of the authority. Warrington L.J. in Short v. Poole Corporation gave the example of the red-haired teacher, dismissed because she had red hair. That is unreasonable in one sense. In another sense it is taking into consideration extraneous matters. It is so unreasonable that it might almost be described as being done in bad faith; and, in fact, all these things largely run into one another. ${ }^{195}$
}

While this brief decision may not have been thought, in its day, to have established a benchmark for the concept of reasonableness, it did just that. Hundreds of decisions since have referred to Wednesbury reasonableness with near reverence. It became applicable to the assessment of whether a tribunal ruling was reasonable, and importantly, it linked

\footnotetext{
$190 \quad$ Ibid at 357.

$191 \quad R$ v Medical Appeal Tribunal; Ex Parte Gilmore, [1957] 1 QB 574 [Gilmore].

$192 \quad$ Ibid at 583.

$193 \quad$ Ibid at 586.

$194 \quad$ Associated Provincial Picture Houses Ltd v Wednesbury Corporation (1947), [1948] 1 KB 223 [Wednesbury]. The enduring vigour of this decision is reflected in Minister for Immigration and Citizenship v Li, [2013] HCA 18, 249 CLR 332. 
reasonableness to error of law. Error of law on the face could, arguably, be demonstrated by unreasonableness.

In light of the foregoing, it cannot be said that the perseverance of the Alberta judges in Picariello was a matter of stubbornly clinging to incoherent judicial opinion. This was not like the colourful description of Justice Scalia of the United States Supreme Court on a different point: "Like some ghoul in a late-night horror movie that repeatedly sits up in its grave and shuffles abroad, after being repeatedly killed and buried, Lemon stalks our Establishment Clause jurisprudence once again.,"196

By the mid-twentieth century, the influential aspects of Nat Bell Liquors, apart from the recognition that jurisdictional defect could justify intervention by certiorari, were the additional observations that (a) it was not entirely obvious why the essential principles of certiorari would not apply equally to civil and criminal matters, and (b) that privative legislation (or at least the 1848 statute) should not be read as denying the foundation — in what Dicey and Coke might both see as the ordinary law of the land — of the basis for certiorari jurisdiction of the superior court. Additionally, with the Denning-esque extensions above, it became arguable that (c) error of law on the face of the record was also a basis for certiorari as well as jurisdiction error, and (d) lack of reasonableness could be just such an error of law.

Absent statute, civil and administrative tribunals would be expected to provide more than a pre-ordained formal ruling without reasons. Tribunal reasons were vulnerable to review. So Lord Sumner's remark that the 1848 statute “did not stint the jurisdiction of the Queen's Bench, or alter the actual law of certiorari" ${ }^{197}$ and the acknowledgment of the concept of “jurisdictional fact” meant Nat Bell Liquors did not push the camel's nose of certiorari out of the "fact review tent."

The Privy Council reasoning was that the Summary Jurisdiction Act, $1848^{198}$ was a practical limit, not a constitutional limit or re-definition. To the extent that legislation was enacted in non-criminal matters with privative clauses seeking to exclude judicial review, the role of judges to interpret that legislation would kick in, just as Lord Mansfield said. ${ }^{199}$ Dicey himself seemed to accept this as no derogation of Parliamentary sovereignty as such:

Parliament is supreme legislator, but from the moment Parliament has uttered its will as lawgiver, that will becomes subject to the interpretation put upon it by the judges of the land, and the judges, who are influenced by the feelings of magistrates no less than by the general spirit of the common law, are disposed to construe statutory exceptions to common law principles in a mode which would not commend itself either to a body of officials or to the Houses of Parliament, if the Houses were called upon to interpret their own enactments. $^{200}$ 
Dicey also asserted that the rule of law, as he felt the beneficiaries of English law had inherited it, embodied three main principles:

(a) the supremacy of "regular law as opposed to the influence of arbitrary power, and [the exclusion of] the existence of arbitrariness, of prerogative, or even of wide discretionary authority on the part of the government”;

(b) the fact of "equality before the law, or the equal subjection of all classes to the ordinary law of the land administered by the ordinary Law Courts” (without special exemptions from obedience); and

(c) the constitutional structure is an architecture of the ordinary law of the land, including foundational notions such as the right to individual freedom (and what we now enumerate expressly in our Charter). These social elements are not "a result deduced" but are "inherent in the ordinary law of the land [such that] the right is one which can hardly be destroyed without a thorough revolution in the institution and manners of the nation."201

Constitutionalism and the rule of law was part of the inheritance of Canada as recognized in the Secession Reference. ${ }^{202}$ While Dicey's taxonomy of the rule of law was not exhaustive, and has been considered debatable in some quarters, it is helpful to take it in as reflecting something of the order of things in 1920 and since.

Less than a decade after Nat Bell Liquors, Lord Chief Justice Hewart was warning that there was increasing quasi-judicial decision-making by the civil service from the growth of delegated legislation. ${ }^{203}$ This movement was "to subordinate Parliament, to evade the Courts, and to render the will, or the caprice, of the Executive unfettered and supreme."204

Hewart's charge apparently created an uproar. The British government moved to defuse his assertion by creating the Donoughmore Committee (chaired by Lord Donoughmore) to review the powers of Ministers. ${ }^{205}$ Unsurprisingly, the Committee in its report did not share Hewart's sense of trepidation. But the rumbles continued. Harold Laski (a member of the Donoughmore Committee) and Sir William Ivor Jennings took up the opportunity to criticize the Dicey concept of the rule of law. ${ }^{206}$

Administrative tribunals of the adjudicative variety, such as labour boards, or professional discipline bodies, or agencies of the Crown dealing with topics like immigration, would be

\footnotetext{
$201 \quad$ Ibid at 197-99.

202 Reference re Secession of Quebec, [1998] 2 SCR 217, notably at para 32 [Secession Reference].

203 The Rt Hon Lord Hewart of Bury, The New Despotism (London, UK: Ernest Benn, 1929).

$204 \quad$ Ibid at 17.

205 UK, HC, "Report of the Committee on Ministers’ Powers,” Cmd 4060 in Sessional Papers, vol 12 (1931-32) 341.

206 W Ivor Jennings, “Administrative Law and Administrative Jurisdiction” (1938) 20: 1 \& 4 J Comp Legis \& Int'l (3d) 99 at 103; W Ivor Jennings, “The Report on Ministers’ Powers” (1932) 10:4 Public Administration 333; W Ivor Jennings, The Law and the Constitution (London, UK: University of London Press, 1933) (dedicated to Harold Laski).
} 
given privative clauses but nothing so obliterating as a sphinx statute. As the powers of the regulatory state developed, a complete barrier to the practical need for reasons would be unacceptable to voters on the receiving end of these emanations of state power.

While Parliament and the executive might want to exclude the surveillance of superior courts, they would find the public unreceptive to laws which allowed such powerful bodies to mete and dole out painful results with no explanation. To paraphrase the period after Tennyson’s "Ulysses,” the “race” was no longer quite so "savage.”207

Resistant to interventions, Canadian executive branches have also used legislative branches to create privative clauses in order to repel judicial intervention. But despite the views of people like Gordon, those statutory devices were ultimately not all that effective in excluding certiorari.

If anything impeded the coherent expansion of certiorari it was the typical incrementalism of the courts themselves. Courts sought to insinuate judicial review into variants on jurisdictional questions, while similarly bouncing around on topics like the differences between decisions that were "legislative,” “executive,” “administrative,” “judicial,” "quasijudicial," or "ministerial." ${ }^{208}$ A lot of this was also due to the incipient development of different standards of review, even if certiorari applied. Safe generalizations would surface, but lead nowhere.

The debate in the middle of the twentieth century in Canada, as administrative law continued to evolve and mature, was reflected in opinion pieces by Laskin ${ }^{209}$ and Willis. ${ }^{210}$ Ultimately, the functionalism of Willis prevailed, even if Laskin is somehow credited with some contribution towards the constitutional entrenchment of judicial review.

One of the privative clauses discussed by Laskin was section 68(1) of The Labour Relations Act of Ontario, ${ }^{211}$ which asserted that a series of decisions of fact "shall be final and conclusive for all purposes" of the Act. This was bolstered by a burly privative statement in section 69 which read:

No decision, order, direction, declaration or ruling of the Board shall be questioned or reviewed in any court, and no order shall be made or process entered, or proceedings taken in any court, whether by way of injunction, declaratory judgment, certiorari, mandamus, prohibition, quo warranto, or otherwise, to question, review, prohibit or restrain the Board or any of its proceedings. ${ }^{212}$

Alfred Tennyson, “Ulysses” in Adam Roberts, ed, Alfred Tennyson: the Major Works (Oxford: Oxford University Press, 2009) 80.

See e.g. FR Scott, “Administrative Law: 1923-1947” (1948) 26:1 Can Bar Rev 268 at 274.

Bora Laskin, "Certiorari to Labour Boards: The Apparent Futility of Privative Clauses” (1952) 30:10

Can Bar Rev 986.

John Willis, “Administrative Law in Canada” (1961) 39:2 Can Bar Rev 251.

Laskin, supra note 209 at 987; The Labour Relations Act, RSO 1950, c 194, s 68(1).

Ibid, s 69. 
To be sure, this was exclusionary language, but it and similar clauses had been circumnavigated despite Laskin's view that review “must bow to the higher authority of a legislature to withdraw this function from [the writs]."213 Laskin said

[w] may well feel that judicial supremacy is the highest of all values under a democratic regime of law, and a value to which even the legislature should pay tribute. But we have not enshrined it in any fundamental constitutional law or in our political system. On the contrary, the cardinal principle of our system of representative government, inherited from Great Britain, has been the supremacy of the legislature. ${ }^{214}$

Laskin further sniffed that "judicial persistence in exercising a reviewing power involves an arrogation of authority only on the basis of constitutional principle (and there is no such principle) or on the basis of some 'elite’ theory of knowing what is best for all concerned.”215

Laskin seemed chagrined that in Globe Printing "the Ontario Court of Appeal did not even bother to mention the privative clause" and it certainly did not block judicial action. ${ }^{216}$ He noted that some courts barely pretended to resist intervention on issues of weight of evidence, but the usual approach was to find errors of law said to be jurisdictional, or "generalized and elusive concepts" of natural justice applied to "various procedural matters." ${ }^{217}$ He also hinted that the devices of collateral issue and jurisdictional fact had been artificially added to the judicial quiver. ${ }^{218}$

Ultimately, though, there was no public uproar, or even legislative rebellion, because courts were "trusted friends in whose company we feel comfortable and for whose protection we are willing to forgive a good deal.”219 Legislatures knew their privative work was being overcome and did nothing. After all, as stated in Roncarelli, "there is always a perspective within which a statute is intended to operate.” ${ }^{220}$ In the end, Laskin said that if this legislative deference to judicial involvement was to continue, "it should be openly conceded and openly established." 221

Not long after this came the Gordon Report in $1959 .^{222}$ The Gordon Report was a surprisingly brief document for one intended to reconfigure the provincial government. But it had large implications for administrative law as it proposed, amongst 48 recommendations, that the legislature get rid of privative clauses and impose on the major agencies a duty to give written reasons, as well as allowing appeals on issues of fact. The Gordon Report did not put the pedal to the metal for certiorari, but it did lend support for the unsympathetic

\footnotetext{
$213 \quad$ Laskin, supra note 209 at 989.

$214 \quad$ Ibid at 990.

$215 \quad$ Ibid at 991.

$216 \quad$ Ibid at 993.

$217 \quad$ Ibid at 995-96.

$218 \quad$ Ibid at 997-98.

$219 \quad$ Ibid at 1001.

220 Roncarelli $v$ Duplessis, [1959] SCR 121 at 140 [Roncarelli].

$221 \quad$ Laskin, supra note 209 at 1002.

222 Ontario, Report of the Committee on the Organization of Government in Ontario (Toronto: The Committee, 1959) (Chair: WL Gordon) [Gordon Report]. Walter Gordon was a significant political figure of his era, being Finance Minister for Canada under Prime Minister Lester Pearson, with whom he later had a falling out.
} 
treatment of privative clauses and did increase the pressure on administrative tribunals to give reasons to explain their decisions.

On the other side of the Gordon Report we find Willis. He tried to write in a "dead pan and non-polemical way" on the topic and refrain "from either lambasting or glorifying Canadian legislatures, governments, civil servants, boards or courts." ${ }^{223}$ He stated that judges of the United States "tower over the whole field of government; they are regarded as priestly oracles, expected 'to know all the answers', and as prophetic guardians of the eternal values against 'Leviathan'.,224 By comparison, Canadian administrative law had a long provenance, but was essentially ad hoc with a law that was "as bewildering and complex as the English.”225 But he suggested that the common thread in all the devices to support review was identifiable: "[i]n a word, the courts have an inherent quasi-constitutional power to guarantee the citizen against arbitrary decision and that is all the power they have."226

As limiting as this may seem, Willis' functional approach carried with it a theme which was given affirmative power when sections 32 and 52 of the Constitution Act, $1982^{227}$ came into force. Once the ultimate character and purpose of judicial review was recognized to be the enforcement of the rule of law, and not merely a form of appellate correction in disguise, the constitutionalization of judicial review was a natural fit to our overall legal reality, not only as governing the legislative and executive branches, but as an internal discipline for the judicial branch.

\title{
IX. Modern Administrative LAW
}

The tension imbedded within judicial review, however, is not exclusively constitutional. It is also practical. On the one hand, the rule of law, when understood as being more inclusive than perhaps Dicey said it was, would suggest that to allow tribunals to be wrong in law, even if it was hard to find them to have acted arbitrarily or unfairly, is a disquieting idea. On the other hand, the complexity of society and the regulation of many specialized activities suggests that courts are simply not the place to examine the substance of such matters. Courts would tend to be as accident-prone as any non-expert. Courts did not want the embarrassment. And the tribunals themselves seemed to be judicializing.

By the mid-twentieth century, the proliferation of boards and tribunals was still in an incipient stage, but the legislatures and Parliament no longer seemed anxious to reverse the turn of the legal earth, whereby certiorari was available. A constitutional crisis did not arise by virtue of the legislatures or Parliament being determined to force the superior courts completely out of tribunal decision making.

Indeed, the attitude reflected in the Gordon Report may well have taken hold. Legislation started to appear with imbedded statutory rights of appeal to the courts notably in the 1980s

\author{
223 Willis, supra note 210 at 251. \\ 224 Ibid at 254. \\ 225 Ibid at 256. \\ $226 \quad$ Ibid at 257. \\ 227 Constitution Act, 1982, being Schedule B to the Canada Act 1982 (UK), 1982, c 11, ss 32, 52.
}


and thereafter. Most legislation dealing with professions has turned that way. Another example was in review of surrender rulings of the Minister of Justice in extradition cases. ${ }^{228}$ Indeed, review of ministerial decisions seems well entrenched now. ${ }^{229}$ Another arises in the Criminal Code provisions as to the surveillance of decisions of a Board of Review. ${ }^{230}$

From their government branch perspective, the courts themselves seem to have chosen to engage in another grand bargain with the legislatures and Parliament, reminiscent of the conceptualization of Holt and Mansfield.

One judicial payment in earnest of such a realignment was New Brunswick Liquor Corporation, ${ }^{231}$ where, without a lot of elaborate language, the Supreme Court pulled the rug out from under the untenable concept of collateral fact (although it lingered for a while like Scalia's “ghoul”). Courts still suggested some obeisance to the legislative opinion on whether board or tribunal decisions should be immune on some issues by continuing to use the language of jurisdiction.

The concept of jurisdiction was increasingly not a matter of compartmentalized investigation, but a matter of whether the tribunal's handling of the matter offended the rule of law. ${ }^{232}$ To clarify the threshold for judicial review in Canada, the "pragmatic and functional" approach started to appear in the Charter era with Bibeault, ${ }^{233}$ even though the Charter was not brought into the discussion.

This approach suggested that the starting point was to determine whether the legislature intended the tribunal's decision on the matters in dispute to be binding on the parties to the dispute. Strictly speaking, this was an interpretation of a "final” decision that could be traced back to Mansfield. More significantly, this was not a matter of whether the decision was binding as a matter of general law. In effect, a sort of (perhaps even subconscious) dialogue between the legislatures and the judiciary, framed as a matter of statutory construction, was growing out of the jurisdictional bramble bush. Standard of review, not the fact of review, came to the forefront. ${ }^{234}$

The Bibeault approach was advanced by Pushpanathan, which detailed a four-part methodology (privative clause, statutory intent and purpose, relative expertise, and nature of the question). ${ }^{235}$ This method was not really aimed at identifying legislative intention as

See e.g. Lake v Canada (Minister of Justice), 2008 SCC 23, [2008] 1 SCR 761. Canada (Attorney General) v PHS Community Services Society, 2011 SCC 44, [2011] 3 SCR 134. See e.g. $R v$ Owen, 2003 SCC 33, [2003] 1 SCR 779.

CUPE v New Brunswick Liquor Corporation, [1979] 2 SCR 227 [New Brunswick Liquor Corporation]. This did not completely kibosh the notion, but by Blanchard v Control Data Canada Ltd, [1984] 2 SCR 476 at 490-91, the absence of any coherent test for distinguishing what is preliminary was confessed. This view has now lasted decades: see e.g. AXA General Insurance Limited v HM Advocate, [2011] UKSC 46, 20121 AC 868 at paras 142-43.

UES Local 298 v Bibeault, [1988] 2 SCR 1048 [Bibeault].

See Canada (Director of Investigation and Research) v Southam Inc, [1997] 1 SCR 748 [Southam]. See also Law Society of New Brunswick v Ryan, 2003 SCC 20, [2003] 1 SCR 247 at paras 24-26; CUPE v Ontario (Minister of Labour), 2003 SCC 29, [2003] 1 SCR 539.

Pushpanathan v Canada (Minister of Citizenship and Immigration), [1998] 1 SCR 982 at paras 29-38 [Pushpanathan]. 
to judicial review jurisdiction, but at identifying the level of deference that should apply to the matter. In other words, Pushpanathan was not about jurisdiction, but whether the court should decline to interfere or not because the tribunal deserved deference. That was a different question. A prudential choice by the court even to decline to intrude was within the court's jurisdiction, not excluded from it.

There were still practical problems in administrative law. Indeed, some called it a "struggle for complexity." ${ }^{236}$ Amongst other things, the four-part Pushpanathan assessment seemed to be demanded even when the court's judicial review authority was not in question, and the standard of review had been decided in previous cases. This added undesirable technicality.

Further, it became increasingly clear that the crucial criterion in the four-part analysis was the issue being examined (for which expertise was a main factor), rather than the primacy of expertise itself, as suggested in Southam. ${ }^{237}$ Finally, the unmanageable and unpredictable character of "patent unreasonableness" as a standard of review invited its demolition.

The Supreme Court of Canada decided to turn the page completely. After a trip across Canada to consult with the appellate courts in every province to get a real feel for where judicial review was in Canada, the Court produced its watershed reasons in Dunsmuir ${ }^{238}$ and Khosa. ${ }^{239}$ In Dunsmuir, Justices Bastarache and LeBel made plain the constitutional foundation of judicial review:

As a matter of constitutional law, judicial review is intimately connected with the preservation of the rule of law. It is essentially that constitutional foundation which explains the purpose of judicial review and guides its function and operation. Judicial review seeks to address an underlying tension between the rule of law and the foundational democratic principle, which finds an expression in the initiatives of Parliament and legislatures to create various administrative bodies and endow them with broad powers. Courts, while exercising their constitutional functions of judicial review, must be sensitive not only to the need to uphold the rule of law, but also to the necessity of avoiding undue interference with the discharge of administrative functions in respect of the matters delegated to administrative bodies by Parliament and legislatures.

By virtue of the rule of law principle, all exercises of public authority must find their source in law. All decision-making powers have legal limits, derived from the enabling statute itself, the common or civil law or the Constitution. Judicial review is the means by which the courts supervise those who exercise statutory powers, to ensure that they do not overstep their legal authority. The function of judicial review is therefore to ensure the legality, the reasonableness and the fairness of the administrative process and its outcomes.

Administrative powers are exercised by decision makers according to statutory regimes that are themselves confined. A decision maker may not exercise authority not specifically assigned to him or her. By acting in the absence of legal authority, the decision maker transgresses the principle of the rule of law. Thus, when 
a reviewing court considers the scope of a decision-making power or the jurisdiction conferred by a statute, the standard of review analysis strives to determine what authority was intended to be given to the body in relation to the subject matter. This is done within the context of the courts' constitutional duty to ensure that public authorities do not overreach their lawful powers. ${ }^{240}$

Dunsmuir also eliminated "patent unreasonableness" and focused the aim of the courts on the "issue." 241 On the other hand, having solidly grounded judicial review in the rule of law, the Court strengthened the internal discipline of courts by an emphasis on deference and on recognition of the range of discretion and fact-finding, either expressly or implicitly given to tribunals.

For its part, Khosa followed upon the view in Dunsmuir that judicial review necessarily embodied judicial discretion to decline to interfere. ${ }^{242}$ This was to reflect the balance contained within the rule of law that real questions of vires and jurisdiction were rare, and that while judicial review is now available whether or not jurisdiction or vires were in issue, the ability of a legislature to fix the standard of review was indicated expressly or implicitly by the statute.

In other words, a legislature has the power to specify a standard of review if it manifests a clear intention to do so. However, where the legislative language permits, the courts (a) will not interpret grounds of review as standards of review, (b) will apply Dunsmuir principles to determine the appropriate approach to judicial review in a particular situation, and (c) will presume the existence of a discretion to grant or withhold relief based on the Dunsmuir teaching of restraint in judicial intervention in administrative matters (as well as other factors such as an applicant's delay, failure to exhaust adequate alternate remedies, mootness, prematurity, bad faith and so forth).

With the crucial focus now being on the issue, deference has been consistently emphasized as a critical feature of the role of the court, notably at the constitutional level when the executive branch may be "better placed to make such decisions within a range of constitutional options." 243 So a presumption of deference to home statute interpretation was adopted. ${ }^{244}$ Similarly, departure from common law concepts applicable to court proceedings did not necessarily oust deference. ${ }^{245}$ But there may be found to be extricable legal error that cannot be accepted because it is an essential question of law shared directly with the regular courts as common to our legal system. ${ }^{246}$

Dunsmuir, supra note 238 at paras 27-29.

Ibid at paras 34, 51-53.

Khosa, supra note 238 at para 25.

Canada (Prime Minister) v Khadr, 2010 SCC 3, [2010] 1 SCR 44 at para 37.

Alberta (Information and Privacy Commissioner) v Alberta Teachers' Association, 2011 SCC 61, [2011] 3 SCR 654 at para 39 [Alberta Teachers].

Nor-Man Regional Health Authority Inc v Manitoba Association of Health Care Professionals, 2011 SCC 59, [2011] 3 SCR 616 at para 52. See also Canada (Canadian Human Rights Commission) $v$ Canada (Attorney General), 2011 SCC 53, [2011] 3 SCR 471.

See e.g. Toronto (City) v CUPE, Local 79, 2003 SCC 63, [2003] 3 SCR 77 at para 62; Rogers Communications Inc v Society of Composers, Authors and Music Publishers of Canada, 2012 SCC 35, [2012] 2 SCR 283 at paras 15-19. 
Another element of the subtle dialogue between the courts and tribunals, as noted above, has been the judicialization of the latter. While the principles of natural justice did not automatically demand reasons, the concept of reasons and fairness did come to be linked by the time of New Brunswick Liquor Corporation and Baker. ${ }^{247}$ Courts were not to discount tribunal decisions solely because of reasoning inadequacy. ${ }^{248}$ But, the movement in the Charter-era to empower tribunals to deal with Charter issues became itself a driving force for encouraging the tribunals to provide reasons on matters properly before the tribunals as a matter of a non-Diceyan and "richer conception" of administrative law. ${ }^{249}$

Ultimately, and with implicit reference to sections 32 and 52 of the Constitution Act, 1982, the Supreme Court in Criminal Lawyers' Association, ${ }^{250}$ put the power of judicial review beyond statutory elimination by installing it within the inherent jurisdiction of the superior court:

\begin{abstract}
With the advent of the Charter, the superior courts' inherent jurisdiction must also support their independence in safeguarding the values and principles the Charter has entrenched in our constitutional order. Thus, the inherent jurisdiction of superior courts provides powers that are essential to the administration of justice and the maintenance of the rule of law and the Constitution. It includes those residual powers required to permit the courts to fulfill the judicial function of administering justice according to law in a regular, orderly and effective manner — subject to any statutory provisions. I would add, however, that the powers recognized as part of the courts' inherent jurisdiction are limited by the separation of powers that exists among the various players in our constitutional order and by the particular institutional capacities that have evolved from that separation. ${ }^{251}$
\end{abstract}

The Supreme Court acknowledged the "amorphous nature” of inherent jurisdiction, ${ }^{252}$ but said that it provided the foundation for powers as diverse as contempt of court, the stay of proceedings, and judicial review. Moreover, it could not be removed except by constitutional amendment, although the procedures for its deployment could be adjusted by a competent legislature. Inherent jurisdiction did not operate without limits, but those were internal to the Constitution itself:

This Court has long recognized that our constitutional framework prescribes different roles for the executive, legislative and judicial branches.... The content of these various constitutional roles has been shaped by the history and evolution of our constitutional order...

Over several centuries of transformation and conflict, the English system evolved from one in which power was centralized in the Crown to one in which the powers of the state were exercised by way of distinct organs with separate functions. The development of separate executive, legislative and judicial functions has

Supra note 231; Baker v Canada (Minister of Citizenship and Immigration), [1999] 2 SCR 817 [Baker]. See Alberta Teachers, supra note 244 at para 55. See also Newfoundland and Labrador Nurses' Union v. Newfoundland and Labrador (Treasury Board), 2011 SCC 62, [2011] 3 SCR 708 at paras 13-16; Agraira v Canada (Public Safety and Emergency Preparedness), 2013 SCC 36, [2013] 2 SCR 559. Doré v Barreau du Québec, 2012 SCC 12, [2012] 1 SCR 395 at paras 29, 35. Ontario v Criminal Lawyers' Association of Ontario, 2013 SCC 43, [2013] 3 SCR 3 [Criminal Lawyers' Association]. Ibid at para 26. Ibid at para 22. 
allowed for the evolution of certain core competencies in the various institutions vested with these functions. The legislative branch makes policy choices, adopts laws and holds the purse strings of government, as only it can authorize the spending of public funds. The executive implements and administers those policy choices and laws with the assistance of a professional public service. The judiciary maintains the rule of law, by interpreting and applying these laws through the independent and impartial adjudication of references and disputes, and protects the fundamental liberties and freedoms guaranteed under the Charter.

All three branches have distinct institutional capacities and play critical and complementary roles in our constitutional democracy. However, each branch will be unable to fulfill its role if it is unduly interfered with by the others. In New Brunswick Broadcasting Co. v. Nova Scotia (Speaker of the House of Assembly), [1993] 1 S.C.R. 319, McLachlin J. affirmed the importance of respecting the separate roles and institutional capacities of Canada's branches of government for our constitutional order, holding that "[i]t is fundamental to the working of government as a whole that all these parts play their proper role. It is equally fundamental that no one of them overstep its bounds, that each show proper deference for the legitimate sphere of activity of the other" (p. 389).

Accordingly, the limits of the court's inherent jurisdiction must be responsive to the proper function of the separate branches of government, lest it upset the balance of roles, responsibilities and capacities that has evolved in our system of governance over the course of centuries.

Indeed, even where courts have the jurisdiction to address matters that fall within the constitutional role of the other branches of government, they must give sufficient weight to the constitutional responsibilities of the legislative and executive branches, as in certain cases the other branch will be "better placed to make such decisions within a range of constitutional options” (Canada (Prime Minister) v. Khadr, 2010 SCC 3, [2010] 1 S.C.R. 44, at para. 37). ${ }^{253}$

As Chief Justice John Marshall said for the United States, "[i]t is emphatically the province and duty of the judicial department to say what the law is."254 Had this power asserted by the Alberta Courts in Nat Bell Liquors been cognizable at that time, the outcome for Nat Bell and his company would have been different.

\section{Constitutionalism Prevails}

As privative clauses became more like netting than barriers, their principal effect came to be in how they influenced the nature of judicial review and the degree of scrutiny applied to specific questions, rather than tuning out certiorari or any other form of judicial review. Indeed, the legislatures' acquiescence in the bypass of such clauses appears to have been almost in the nature of a dialogue between the two branches of government to achieve a sound and acceptable framework for judicial review (or statutory appeals), whereunder the regular courts' surveillance was linked to and limited by the rule of law.

In the end result, twelve bottles of whiskey brought about a sea change in the foundational law of Canada. While Nat Bell and his company paid a price, the attitude that worked against him also worked against itself. It illuminated the unsatisfactory state of the rule of law in 
relation to agencies of the state at precisely the right time. Howsoever unsympathetic the Alberta legislature was to Nat Bell, the Alberta courts saw the matter as touching on judicial protection of rights and freedoms that the courts must always be vigilant to protect.

The attention that later courts gave to this topic gradually lost sight of the liquor business in central Edmonton in 1920. But the evolution to a constitutionally entrenched but internal circumspect and deferential form of judicial review (albeit one which did not refrain from review of fact or law) was touched by it. This occurred in a way fairly described by legal historian Maine: the "substantive law has at first the look of being gradually secreted in the interstices of procedure; and the early lawyer can only see the law through the envelope of its technical forms." 255 